\title{
The risks of overlooking the diagnosis of secreting pituitary adenomas
}

Thierry Brue ${ }^{1,2^{*}}$ and Frederic Castinetti ${ }^{1}$

\begin{abstract}
Secreting pituitary adenomas that cause acromegaly and Cushing's disease, as well as prolactinomas and thyrotroph adenomas, are uncommon, usually benign, slow-growing tumours. The rarity of these conditions means that their diagnosis is not familiar to most non-specialist physicians. Consequently, pituitary adenomas may be overlooked and remain untreated, and affected individuals may develop serious comorbidities that reduce their quality of life and life expectancy. Because many signs and symptoms of pituitary adenomas overlap with those of other, more common disorders, general practitioners and non-endocrinology specialists need to be aware of the "red flags" suggestive of these conditions. A long duration of active disease in patients with secreting pituitary adenomas is associated with an increased risk of comorbidities and reduced quality of life. Appropriate treatment can lead to disease remission, and, although some symptoms may persist in some patients, treatment usually reduces the incidence and severity of comorbidities and improves quality of life. Therefore, correct, early diagnosis and characterization of a pituitary adenoma is crucial for patients, to trigger timely, appropriate treatment and to optimize outcome. This article provides an overview of the epidemiology of hormonal syndromes associated with pituitary adenomas, discusses the difficulties of and considerations for their diagnosis, and reviews the comorbidities that may develop, but can be prevented, by accurate diagnosis and appropriate treatment. We hope this review will help general practitioners and non-endocrinology specialists to suspect secreting pituitary adenomas and refer patients to an endocrinologist for confirmation of the diagnosis and treatment.
\end{abstract}

Keywords: Acromegaly, Cushing's disease, Pituitary neoplasms, Prolactinoma, Hyperthyroidism, Pituitary hormones

\section{Background}

Pituitary adenomas are usually benign, slow-growing tumours; those that secrete an active hormone are known as "hormonally active" or "functional tumours" and, unlike the so-called "non-functioning" pituitary adenomas, lead to diseases of excessive hormone secretion. The secreting pituitary adenomas include those that cause acromegaly and Cushing's disease as well as prolactinomas and thyrotroph adenomas. Although gonadotroph adenomas may exceptionally trigger symptoms related to gonadotropin hypersecretion, they account for the vast majority of nonfunctioning pituitary adenomas and therefore will not be discussed in the present review $[1,2]$.

All types of pituitary adenomas may compress surrounding structures, primarily the normal pituitary gland

\footnotetext{
* Correspondence: thierry.brue@ap-hm.fr

${ }^{1}$ Hôpital de la Conception 147, Boulevard Baille, 13285 Marseille Cedex 05, France

${ }^{2}$ Pôle ENDO (Endocrinologie Nutrition Diabète Obésité), 147 Boulevard Baille, 13285 Marseille Cedex 5, France
}

(c) 2016 The Author(s). Open Access This article is distributed under the terms of the Creative Commons Attribution 4.0 International License (http://creativecommons.org/licenses/by/4.0/), which permits unrestricted use, distribution, and reproduction in any medium, provided you give appropriate credit to the original author(s) and the source, provide a link to the Creative Commons license, and indicate if changes were made. The Creative Commons Public Domain Dedication waiver (http://creativecommons.org/publicdomain/zero/1.0/) applies to the data made available in this article, unless otherwise stated.

and optic pathways, thus causing symptoms of hypopituitarism, headaches, and visual disturbance [3, 4]. Despite their benign nature, pituitary adenomas may invade the adjacent cavernous sinus, a feature making anatomical and histological invasion a key prognostic factor for these tumours [5-8] and a basis for their classification [9]. However, the present article will focus on the manifold consequences of pituitary hormone overproduction by the different types of hormonally active adenomas. Acromegaly is caused by hypersecretion of growth hormone $(\mathrm{GH})$, which leads to increased levels of circulating insulin-like growth factor 1 (IGF-1) [10], and Cushing's disease arises from chronic hypercortisolism associated with oversecretion of adrenocorticotropic hormone (ACTH) [11]. In patients with prolactinomas, excess prolactin can lead to gonadal dysfunction due to decreased levels of oestrogen in women and testosterone in men, and to oligo-amenorrhoea and galactorrhoea in premenopausal women. Prolactinomas in any adult 
patient can cause gonadal dysfunction and infertility. Finally, thyrotroph adenomas can lead to hyperthyroidism with inappropriately normal or increased thyroidstimulating hormone (TSH) levels [4].

Secreting pituitary adenomas clearly meet the European definition of rare diseases, because they affect fewer than 1 in 2,000 individuals. Therefore most non-specialist physicians have limited experience of these conditions. In addition, many signs and symptoms overlap with those of other, more common, disorders and may be overlooked. General practitioners (GPs), to whom patients may present, and non-endocrinology specialists, to whom patients may be initially referred, therefore need to be aware of the "red flags" suggestive of a pituitary adenoma when making a diagnosis. Additionally, the techniques and assays used for biochemical diagnosis may present difficulties in routine use in the clinical setting. These factors combined mean that diagnosis of these disease states, particularly acromegaly and Cushing's disease, may be delayed.

Generally, in patients with pituitary adenomas, a long duration of active disease is associated with an increased risk of comorbidities and decreased quality of life, so treatment should be started as soon as possible to prevent or at least limit deleterious effects of hormone excess. Compared with no treatment, appropriate treatment (surgical removal of the tumour and pharmacological management, if needed, followed by radiotherapy) can lead to disease remission, improved quality of life, decreased incidence and severity of comorbidities, and lower mortality $[3,4,10,12,13]$. A correct and early diagnosis is therefore crucial for patients, to trigger appropriately early treatment and to optimize outcomes.

To assist GPs and non-endocrinology specialists in recognizing and managing secreting pituitary adenomas, this review provides an overview of the epidemiology of these conditions, discusses the difficulties of their diagnosis, and examines associated comorbidities that may be prevented by accurate, early diagnosis, and appropriate treatment.

\section{Difficulties with diagnosis of secreting pituitary adenomas and consequences of delayed diagnosis}

Historically, secreting pituitary adenomas were considered to be particularly rare. In general, however, autopsy and radiological studies reveal pituitary adenomas in 15-20\% of normal subjects $[14,15]$. As diagnostic techniques have progressed, in particular the availability of specific, sensitive biochemical assays, more accurate epidemiological data on these tumours are becoming available [14-16].

Differential diagnosis of secreting pituitary adenomas is based on biochemical evaluation and imaging to assess the extent of hormone hypersecretion and to identify the location and size of tumours. Conditions associated with pituitary adenomas present in non-specific ways at an early stage, making diagnosis from clinical signs and symptoms at presentation challenging, and resulting in the possibility of diagnostic delay. Diagnosis may be further complicated and delayed by subclinical disease, the slow manifestation of symptoms in these chronic conditions, and the extensive overlap of signs and symptoms with those of other diseases [4, 13, 17-19], as discussed below. Patients are often referred to a specialist because of a certain symptom (for instance to a dermatologist for purple striae, to a rheumatologist for joint pain, to a psychiatrist for mood changes, etc.), but the non-endocrinology specialist may not consider features beyond their specialty or be aware of a complete history of the disease, and this factor may also contribute to a delay in diagnosis of a secreting pituitary adenoma.

Because changes in appearance due to acromegaly and Cushing's disease generally occur slowly, they are often overlooked by family members, friends, GPs, and the patients themselves. There is increasing support for the development of automated diagnostic tools that would potentially aid the diagnostic process, including facerecognition software to identify the characteristic physical changes associated with these conditions [20-22], or 3dimensional cephalometry [23]. However, such approaches have to date been applied only to limited numbers of subjects in pioneering studies.

The consequences of delayed diagnosis are an increased number and severity of complications, delayed intervention, a reduced quality of life for patients, and an increased risk of mortality. Therefore, early diagnosis is important. It allows timely intervention and the initiation of appropriate treatment, thus limiting the complications and sequelae of these conditions and allowing the possibility of remission in some cases. However, as pituitary disorders are rare and the costs of tests are relatively high, routine screening may be difficult to justify in many countries.

Finally, it must be kept in mind that pituitary adenomas may rarely be part of a type 1 multiple endocrine neoplasia (MEN-1) syndrome that also includes primary hyperparathyroidism and gastroenteropancreatic endocrine tumours. In such a setting, overlooking a diagnosis of pituitary adenoma may be particularly harmful [24].

\section{Acromegaly}

The reported incidence of $\mathrm{GH}$-secreting adenomas that cause acromegaly is $1-4$ per million per year [25-30], with a prevalence of $27-97$ per million [25-27, 30-34]. However, these figures may be underestimates of the true number of patients with acromegaly, and some studies suggest that the condition is more common: an incidence of 11 cases per million per year was recently found from an analysis of a large US health-plan database [34], and a German study reported a prevalence of 
1,034 per million [35]. It is currently not known who is at risk of a GH-secreting adenoma. Acromegaly is slightly more common in females than in males, but men tend to be diagnosed with the disorder earlier in life than women, usually before 45 years of age [26, 28, 31, 36-41].

Acromegaly is characterized by slowly progressive somatic disfigurement and systemic manifestations as depicted in Fig. 1, at the maximal reported rates shown in Fig. 2. For differential diagnosis, the most recent joint United States Endocrine Society and European Society of Endocrinology Clinical Practice Guideline for acromegaly recommends measurement of IGF-1 levels in patients with typical clinical manifestations of acromegaly, especially those with acral and facial features (Fig. 1) [10]. As a result of the overlap of symptoms with those of other conditions such as sleep apnoea syndrome, type 2 diabetes mellitus, arthritis, carpal tunnel syndrome, hyperhidrosis, hypertension, and cardiac disease (arrhythmias, left ventricular hypertrophy, and diastolic dysfunction), IGF-1 levels should be tested in patients without the typical features of acromegaly but who have symptoms of these conditions [10, 42, 43]. In a case of suspected acromegaly, an elevated IGF-1 level and a failure to suppress GH below $1 \mathrm{ng} / \mathrm{mL}$ during an oral glucose tolerance test (OGTT) confirm the diagnosis [10, 44].

\section{Difficulties with diagnosis}

The slow manifestation of symptoms means that there is an average delay in diagnosis of acromegaly of 6-7 years after the first appearance of symptoms; in some patients, it may take as long as 35 years [26, 33, 41, 45]. Such a delay is partially related to the fact that slowly progressing changes in physical features may remain unnoticed by patients and the people around them until the first manifestation of complications.

It is important to be aware of a number of facts related to interpretation of test results that may complicate a diagnosis of acromegaly. Difficulties in interpreting GH level are related to the pulsatility of $\mathrm{GH}$ secretion, which is absent in patients with acromegaly. Increasing age, female gender, and obesity can be associated with abnormal GH suppression in response to OGTT [10]. A random $\mathrm{GH}>30 \mathrm{ng} / \mathrm{mL}$ can be seen in patients without acromegaly.

Because IGF-1 levels decrease with age after adolescence [46], they must be assessed in relation to ageand gender-appropriate normal values for the specific assay used [10]. Falsely positive diagnoses may be made in late-stage adolescent patients or during pregnancy [10]. Patients taking oral oestrogens may have low IGF1 levels. Also, patients with hepatic or renal failure, hypothyroidism, malnutrition, severe infection, hepatic disease, or poorly controlled diabetes mellitus may have

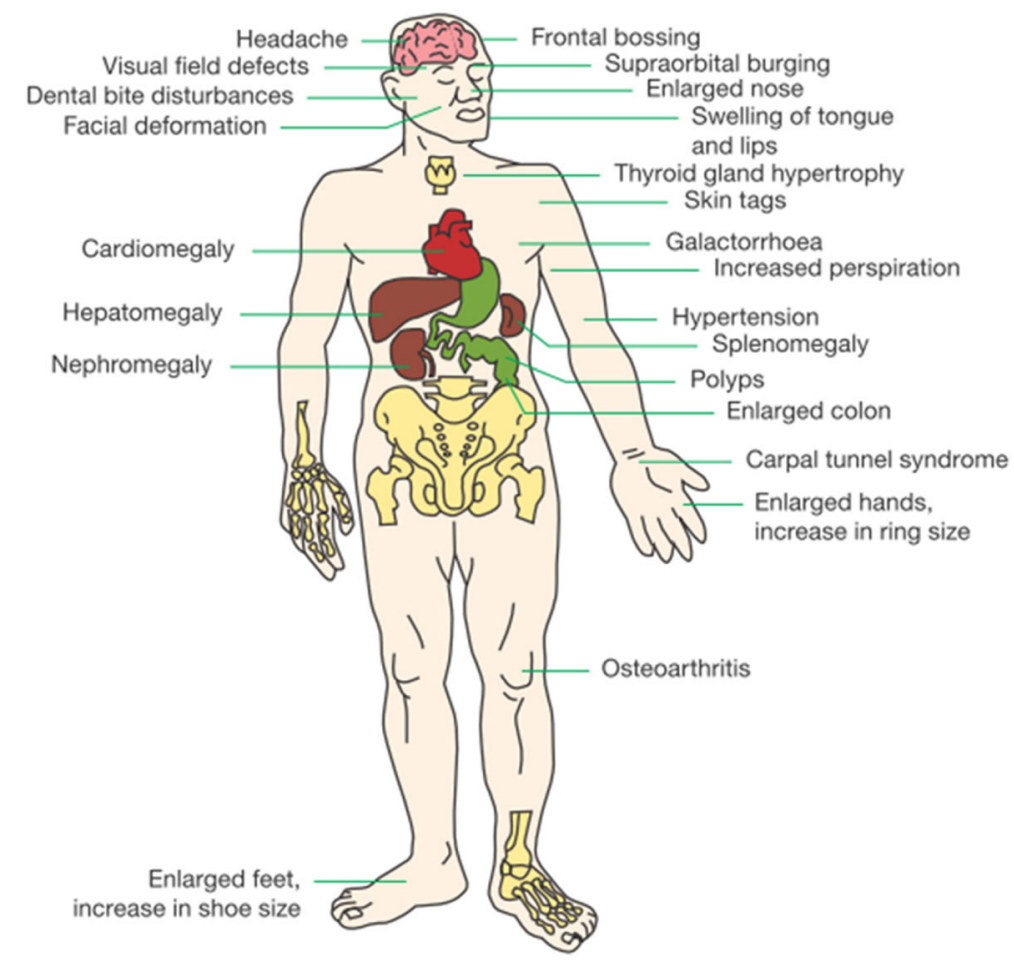

Fig. 1 Typical features of acromegaly 


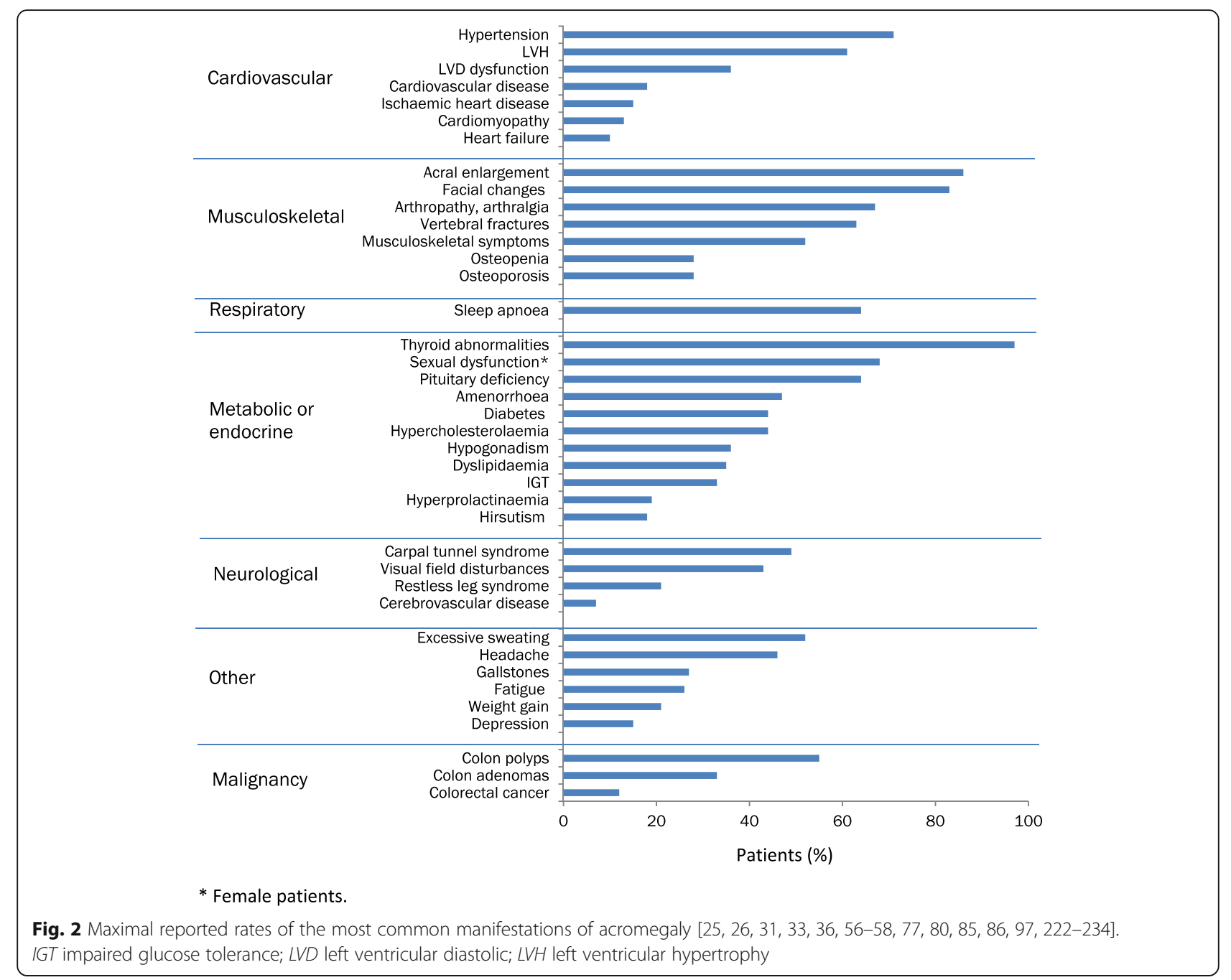

abnormal IGF-1 levels compared with healthy individuals [47-49]. In addition, because variability between GH and IGF-1 assays used at different laboratories is significant, and standardization of assays is lacking, correct interpretation of results requires knowledge of the specific assay used [10, 44, 50, 51].

A challenging diagnostic issue presents in patients with diabetes mellitus, because these patients can have an abnormal IGF-1 level or an abnormal response to OGTT (or both) [10, 52]. In diabetic patients, diagnosis is usually based on readouts from multi-sample day curves for $\mathrm{GH}$, and $\mathrm{GH}$ values $>1 \mathrm{ng} / \mathrm{mL}$ are considered abnormal. Re-evaluation by a specialized endocrinologist is highly recommended in these patients.

There is still an unmet need for validated symptomscoring tools aiding recognition of patients with acromegaly, and research is providing some tools that may become clinically useful in due course [53-55]. The ACROSCORE is a 14-point scoring system based on the cardinal symptoms and signs of acromegaly and developed for the clinical screening of acromegaly [55]. Although still not validated, the ACROSCORE might become an easy-to-use tool to diagnose acromegaly early in the disease course, thus allowing patients with acromegaly to be distinguished from those in whom acromegaly has been ruled out.

Other tools in development combine biochemical and clinical parameters to measure disease activity, and they could be useful not only for diagnosis of acromegaly, but also for evaluating the effects of treatment $[53,54]$. The SAGIT instrument is a comprehensive clinician-reported outcome tool to assess the key features of acromegaly and thus assist endocrinologists managing acromegaly in practice, with promising results from a pilot study [53]. SAGIT combines signs and symptoms, associated comorbidities, GH levels, IGF-1 levels, and tumour profile. Finally, ACRODAT is a decision algorithm based on IGF-1 level (SD score), tumour status (change on magnetic resonance imaging), comorbidities (number and severity), signs and symptoms (Patient Acromegaly Symptom Questionnaire score), and health-related quality 
of life (scored on a disease-specific measure) [54]. In a modelling exercise performed for this score, biochemical and tumour statuses were shown to be the primary predictors of disease activity [54].

\section{Consequences of delayed diagnosis}

Earlier diagnosis and treatment, as well as appropriate follow-up, may potentially limit or avoid the life-long consequences of uncontrolled disease and reduce mortality risk. On the other hand, late diagnosis and therefore long-term exposure to GH and IGF-1 excess may result in comorbidities that are difficult to manage and, in some cases, may persist even after biochemical control is achieved. The most serious long-term consequences of untreated acromegaly are hypertension, cardiovascular disease, diabetes, arthropathies, and obstructive sleep apnoea $[25,29,31,56-60]$ and patients have significant deterioration in quality of life [61].

Hypertension and diabetes are very important risk factors for cardiovascular disease in patients with acromegaly, and approximately half of patients are at intermediate or high risk of coronary artery disease [62]. Patients with an estimated disease duration of longer than 10 years have a threefold higher relative risk of cardiac complications than do patients with an estimated disease duration of 5 years or less [63]. In normal health, GH and IGF-1 have a regulatory role in the cardiovascular system, and patients with elevated GH and IGF-1 levels therefore often demonstrate both structural and functional abnormalities and diastolic dysfunction, as well as abnormalities in the vascular system. Early symptoms of acromegalyassociated cardiomyopathy include cardiac hypertrophy, an elevated heart rate, and increased systolic dysfunction [42, 59, 60, 62, 63]. If left untreated, these initial symptoms may develop into more pronounced hypertrophy, diastolic dysfunction, and systolic insufficiency during exercise [59]. The standardized mortality ratio for patients with acromegaly ranges from 1.1 to 3.2 in different countries [25, 26, 36, 37, 64-66], with the main causes of death being cardiovascular disease, cerebrovascular disorders, and respiratory disorders [28, 36, 37, 65, 67, 68].

Early diagnosis and early initiation of treatment in acromegalic patients can prevent the progression of cardiovascular disease and reduce the risk of premature death [69]. However, it is still unknown for how long cardiovascular comorbidities remain reversible. Although treatment to reduce GH and IGF-1 levels can decrease risk of cardiac hypertrophy and arrhythmias, as well as improve diastolic function [70], improvements in systolic function and response to exercise depend mostly on disease duration and the presence of hypertension and diabetes [63]. Coronary artery calcifications correlate with disease duration [71], but the clinical impact of treatment on coronary artery disease remains unknown. Hypertension is the main contributor to increased mortality in acromegaly and, unlike hyperglycaemia (which resolves in the majority of patients in remission), it persists in most cases after biochemical control is achieved [72, 73]. With regard to hyperglycaemia, $\mathrm{GH}$ excess contributes to the development of insulin resistance [74] and endothelial dysfunction [75]. Cardiovascular risk factors for hyperglycaemia, such as glucose homeostasis alterations, may also be present in acromegalic patients despite long-lasting GH/IGF-1 control [76].

Joint problems, such as arthralgia, are common symptoms, occurring in at least half of patients with acromegaly $[25,77]$. Although reduction in joint thickness upon disease control has been observed, some joint problems may persist despite treatment for acromegaly $[69,78,79]$. Due to its mechanism, arthropathy may be reversed with early treatment for acromegaly, but this is less likely if the disease has been left untreated for several years [80, 81]. Patients with acromegaly are at increased risk of vertebral fractures, but the impact of acromegaly on bone mineral density (BMD) is still unclear [82-84]. Fracture risk is significantly associated with the duration of uncontrolled disease $[83,85]$. Although BMD has been shown to improve upon biochemical control, risk of vertebral fractures persists in some patients $[85,86]$.

In addition to physical impairment, sleep apnoea is more common and more severe in patients with active acromegaly than in those with controlled disease [87-89]. The apnoea-hypopnoea index and tongue volume have been shown to be reduced on normalization of IGF-1 in treated patients [89, 90].

Patients with acromegaly also display impairment of cognitive performance, particularly in memory tests $[58,91]$, and increased anxiety-related personality traits [56]. A longer duration of uncontrolled acromegaly may be associated with neurocognitive complications of greater severity. Conversely, a longer duration of postoperative biochemical remission of acromegaly is associated with a better neurocognitive state [58]. Improvements in cognition and mental health upon control of acromegaly appear to be only partial: memory recall, concentration, learning capability, and accuracy remain impaired in patients with controlled disease compared with healthy control subjects [58].

Several studies have suggested an increased risk of cancer (including those originating from intestines, brain, breast, thyroid, uterus, prostate, kidney, and skin) in patients with acromegaly [92-95]. However, in the most recent analysis of 446 patients from the German Acromegaly Registry, the overall cancer rate was slightly lower than that in the general population and not significantly higher for colorectal, breast, thyroid, prostate, and lung cancers [96]. Although IGF-1 has been shown to play a role in the development of cancerous changes in thyroid cells, an expected association of thyroid 
cancer with acromegaly remains controversial. Although some studies demonstrated thyroid cancer in $4.7-5.6 \%$ of patients with acromegaly $[92,97,98]$, a rate slightly higher than that in the general population, others found no increase in the prevalence of thyroid cancer in acromegalic patients compared with the general population $[96,99]$.

In summary, prevention of development of comorbidities associated with GH or IGF-1 excess in patients with acromegaly through early diagnosis and treatment is of great importance. The "red flags" that should trigger further investigations for acromegaly include: a long duration of signs and symptoms such as arthralgia and sleep apnoea; early onset of cardiovascular disease, impaired glucose and lipid metabolism, and osteoporosis and vertebral fractures; persistence of symptoms such as hypertension, impaired glucose metabolism, and arthralgia despite treatment; atypical diabetes; and bilateral carpal tunnel syndrome. Early intervention may limit the development of deleterious consequences of GH or IGF-1 excess.

\section{Cushing's disease}

The incidence of Cushing's disease is estimated at 1.2-2.4 per million per year $[100,101]$, with a prevalence of 29.1 per million population [100]. Like acromegaly, Cushing's disease is more common in females than in males, with a reported male-to-female ratio between 1:1.5 and 1:15 [100-115]. As with acromegaly, the true number of patients with Cushing's disease may be underestimated. This is because Cushing's disease is also found in people who are initially diagnosed with pituitary incidentalomas [116] and may also be unrecognised in individuals diagnosed with diabetes, hypertension, or depression [117-120]. For example, it has been reported that $9 \%$ of patients with type 2 diabetes also fulfil the criteria for subclinical Cushing's disease [121].

A diagnosis of Cushing's syndrome is the usual first step for a diagnosis of Cushing's disease and can be made once non-pituitary causes of hypercortisolism have been excluded. Detection relies first on clinical suspicion followed by biochemical confirmation [122]. The signs and symptoms of Cushing's disease are widespread (Fig. 3), and some symptoms and complications are more frequent in males than in females. These include purple striae, muscle atrophy, osteoporosis, and nephrolithiasis [111]. The most common manifestations of Cushing's disease are cardiovascular, metabolic, or endocrine disorders, central obesity, and dermatological features (for instance easy bruising, red face) $[123,124]$; the relative incidence of the various manifestations of Cushing's disease are summarized in Fig. 4. A definitive diagnosis of hypercortisolism can be established by repeat measurements of an elevated 24-h urinary free cortisol (UFC) concentration. Alternatively, late-night salivary cortisol levels support the diagnosis if there is a loss of the circadian rhythm of cortisol levels. Endogenous hypercortisolism is confirmed if there is a lack of cortisol suppression (below an adequate threshold, usually $50 \mathrm{nmol} / \mathrm{L})$ after a low-dose $(1 \mathrm{mg})$ overnight dexamethasone suppression test [125].

\section{Difficulties with diagnosis}

The clinical presentation of Cushing's syndrome or disease varies depending on the severity and duration of hypercortisolism [122]. In severe, overt hypercortisolism, the signs and symptoms (e.g. proximal muscle weakness, increased abdominal or facial fat, wasting of extremities, and wide purple striae) can easily be attributed to Cushing's disease, but in many patients, not all the symptoms characteristic of Cushing's disease are present, and patients with subclinical cortisol secretion or cyclic hypercortisolism may not present in a classical way [126]. Common manifestations are central weight gain, hypertension, and changes in memory, mood, and concentration. As with acromegaly, the overlap of many of the signs and symptoms of this disease with those of other conditions (such as obesity, metabolic syndrome, diabetes mellitus, hypertension, and depression) contribute to delayed diagnosis of typically 2 to 6 years after the first appearance of symptoms [19, 103, 127].

Difficulties with diagnosis may also relate to the interpretation of biochemical tests. Normal cortisol levels fluctuate in a circadian pattern; therefore, multiple tests are required to reduce the risk of false-positive or false-negative results $[128,129]$. In addition, some patients (with pseudoCushing's syndrome) may have an elevated UFC or abnormal response to dexamethasone (or both) and some symptoms suggestive of Cushing's syndrome despite absence of the disease [130]. Pseudo-Cushing's syndrome can be associated with chronic alcohol consumption, depression, severe obesity, and chronic stress [131].

Additionally, use of biochemical tests for Cushing's disease in routine clinical practice may not be optimal, because multiple protocols and different cut-off criteria often exist for each assay [132]. Therefore expertise is needed to conduct the tests and interpret the results $[129,133]$.

Furthermore, many steroid medications (glucocorticoids, inhaled and topical corticosteroids, oral oestrogens) and treatment combinations including ritonavir affect cortisol levels; in some cases, this can lead to symptoms of hypercortisolism as well as affect the diagnostic utility of the results $[125,134-141]$.

\section{Consequences of delayed diagnosis}

Overproduction of ACTH in patients with pituitary adenomas leads to hyperstimulation of the adrenal glands and a chronic excess of cortisol, with deleterious effects on most tissues of the body (Fig. 4), negative effects on the patient's quality of life $[13,61,142]$, and, if untreated, 




Fig. 3 Signs and symptoms of Cushing's disease

increased mortality $[143,144]$. Mortality rates are up to 9 times higher in patients with untreated Cushing's disease than in the general population [101, 107, 110, 115, 145]. The main complications of untreated Cushing's disease include: hypertension; metabolic diseases such as impaired glucose tolerance, diabetes, and metabolic syndrome; myopathy; and bone-related complications such as osteoporosis and fractures [100, 104, 111, 112, 114, 116, 146-148].

Cure of the disease or at least control of hypercortisolism does not necessarily mean disappearance of comorbidities. Irreversibility of some of the complications is likely to be caused by a prolonged exposure to high cortisol levels due to the delay in diagnosis. This situation clearly emphasizes the need for greater awareness among physicians of the main "red flags" that should trigger testing for chronic hypercortisolism - uncontrolled hypertension possibly associated with hypokalaemia, atypical acquired diabetes mellitus, osteoporosis with or without vertebral fractures, hyperandrogenism and overweight (in women with a centripetal obesity), or thin skin - in patients who are younger than expected for these conditions [13].

Many cardiovascular risk factors, including hypertension, diabetes, obesity, and dyslipidaemia, are improved upon resolution of hypercortisolism, but an increased cardiovascular risk may persist and manifest in the long term [149-153]. Patients with Cushing's disease have severe atherosclerotic damage; persistence of metabolic syndrome, vascular damage, and atherosclerotic plaques after normalization of cortisol levels contributes to a high cardiovascular risk despite treatment [150, 154]. Up to $2 \%$ of patients with hypercortisolism die as a consequence of a thromboembolic event [155]. Factors contributing to the increased thromboembolic risk include a long duration of uncontrolled hypercortisolism, glucocorticoid-induced hypercoagulability, and obesity [112, 154]. This risk is thought to be already present $1-2$ years before diagnosis of Cushing's disease and may remain for months after surgery [113]. However, other studies report that 6 months after disease control, thromboembolic risk returns to the degree of risk seen in healthy individuals [156].

In general, the level of hypercortisolism correlates with the presence of impaired glucose tolerance, impaired insulin resistance, and diabetes [151]. Even 5 years after remission of Cushing's syndrome, impaired glucose tolerance may persist [149]. Chronic hypercortisolism results in changes in body fat deposition and increased abdominal adiposity, with related metabolic consequences. Additionally, effects of excess cortisol in the brain can influence eating behaviour, with further contribution to the obese phenotype of patients with Cushing's disease [157]. If the disease is controlled, significant reductions in total, abdominal visceral, subcutaneous, and bone marrow adipose tissue can be achieved, but 


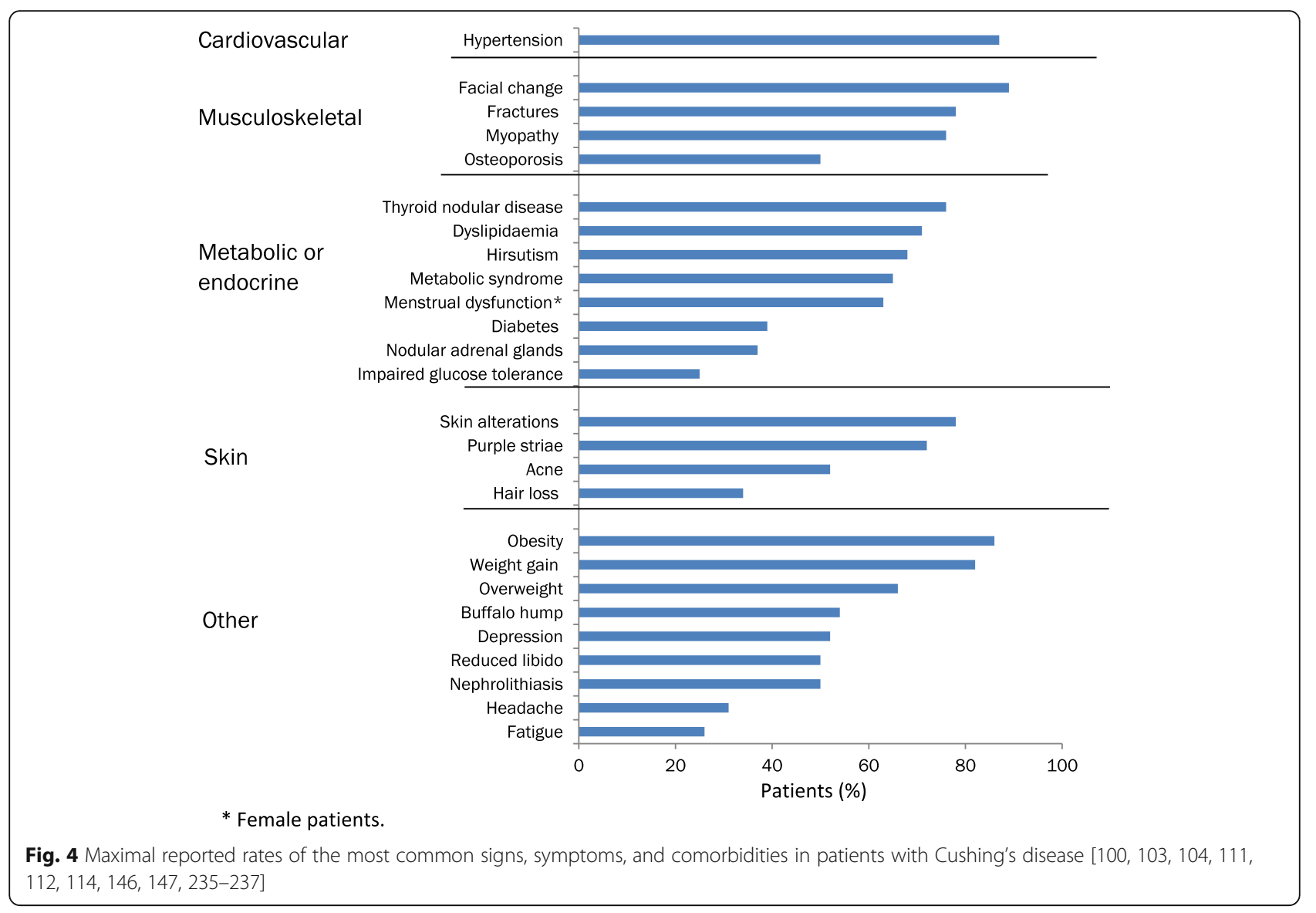

most patients remain overweight or obese in the long term and remain at risk of cardiovascular disease [158, 159]. Dyslipidaemia tends to improve with correction of hypercortisolism, but complete normalization of lipid levels is usually not achieved, even after long-term remission $[149,150]$.

There are no specific studies on or guidelines for the management of cardiovascular risk factors in patients with Cushing's disease. Nevertheless, based on the fact that these patients are usually at high or very high cardiovascular risk, standard practice should be applied to managing any cardiovascular risk factors that manifest in patients. Follow-up is recommended in the active phase of the disease and in the long term, because of the possible persistence of these risk factors after treatment-induced remission [160, 161]. The patient's cardiovascular risk profile should be evaluated at least yearly. Hypertension, hyperglycaemia, and dyslipidaemia should be adequately treated, and particular attention should be paid to patients in remission for whom a more aggressive approach is recommended [160, 161].

Prolonged exposure to cortisol excess is detrimental to bone: reduced BMD and increased risk of osteoporosis and fractures can result [162, 163]. A study of a large consecutive cohort of 104 patients with Cushing's syndrome demonstrated that the increased risk of fracture was confined to the last 2 years before diagnosis and the start of therapy; it reverted to normal after diagnosis and treatment [164]. This observation further supports the importance of prompt and accurate diagnosis of Cushing's disease to prevent the effects of hypercortisolism on bone structure.

In addition, cortisol excess negatively affects the structure and function of brain tissue. Patients with active Cushing's syndrome have a smaller hippocampus, enlarged ventricles, cerebral atrophy, and altered neurochemical concentrations and functional activity [165]. Some studies point to alterations in brain activity related to symptoms of depression and emotional memory in patients with hypercortisolism [166]. After treatment and abrogation of cortisol excess, when the patient is in long-term remission, structural and neurochemical alterations in brain tissue improve and correlate with improvements in clinical and behavioural outcomes. However, abnormalities in grey and white matter are not completely reversible and are associated with persistent psychological symptoms and impairments in cognitive functioning $[165,167]$. 


\section{Prolactinomas}

Prolactinomas remain the most common secreting pituitary tumours [168, 169], accounting for $40-66 \%$ of clinically relevant cases [3, 170, 171]. A recently published Swedish study by Tjörnstrand et al. reported a standardized incidence rate (SIR) of 1.6 per 100,000 adult patients diagnosed with pituitary adenomas in one county between 2001 and 2011 (accounting for $32 \%$ of all pituitary adenomas) [172]. Finnish data support these findings: a SIR of 2.2 per 100,000 (51 \% of all pituitary adenomas) has been reported [173]. Prolactinomas have an estimated prevalence of approximately $35-50$ per 100,000 inhabitants $[16,33,174]$ and occur most frequently in women aged $20-50$ years, with a female-to-male ratio of approximately 10:1 [175].

The effects of hyperprolactinaemia in adult patients commonly include hypogonadism, infertility, sexual dysfunction, low BMD, and effects on the mammary glands (gynaecomastia, galactorrhoea) [176-178]. During adolescence, delayed onset of puberty, oligo-amenorrhoea, and galactorrhoea may be seen in girls, and boys may have delayed pubertal development and hypogonadism [3]. "Red flags" that should trigger suspicion of prolactinoma are amenorrhoea or irregular menses associated with (inconstant) galactorrhoea, and sexual dysfunction in males.

Diagnosis of hyperprolactinaemia and identification of its cause can be based on medical history, physical examination, clinical features, serum prolactin levels, biological investigations, and imaging of the pituitary region $[179,180]$. The current Clinical Practice Guideline from the Endocrine Society for the diagnosis of hyperprolactinaemia recommends a single measurement of serum prolactin, with diagnosis confirmed by a level above the upper limit of normal. Nevertheless, to account for possible prolactin pulsatility, multiple sampling (at 15- to 20-minute intervals) may be useful in confirmation of diagnosis of hyperprolactinaemia [3]. Assayspecific normal values for prolactin are higher in women than in men and generally lower than $25 \mu \mathrm{g} / \mathrm{L}$ [3]. Prolactin levels higher than $500 \mu \mathrm{g} / \mathrm{L}$ are diagnostic of macroprolactinomas [181].

In contrast with the available biochemical assays for diagnosis of acromegaly and Cushing's disease, those for prolactinoma are roughly comparable, and assessment is usually uncomplicated in the clinical setting [3]. However, in patients with very large prolactinomas $(>3 \mathrm{~cm})$, prolactin assays may falsely provide a lower-than-actual prolactin level because of antibody saturation. Further dilution of the sample is needed to avoid this potential trap [182].

\section{Considerations for accurate diagnosis}

The clinical presentation of prolactinoma is genderspecific. Women typically seek medical consultation because of the classic amenorrhoea-galactorrhoea syndrome associated with the condition, whereas men present with more general symptoms such as headache, gynaecomastia, impotence, and reduced libido [171]. Although galactorrhoea is the most characteristic manifestation of hyperprolactinaemia, it may not be present or may only manifest intermittently [183]. Up to $50 \%$ of women with galactorrhoea have normal prolactin levels [184], but amenorrhoea associated with galactorrhoea strongly suggests hyperprolactinaemia [185].

Hyperprolactinaemia can be caused by a number of different conditions, which should be considered and ruled out to make a differential diagnosis. Some patients with non-functioning pituitary adenomas have hyperprolactinaemia resulting from compression of the pituitary stalk and are at risk of misdiagnosis [186]. Patients with acromegaly may occasionally present with markedly elevated levels of prolactin in cases of $\mathrm{GH}$ - or prolactin-secreting adenomas [187], and hyperprolactinaemia may occur in a subset of patients with primary hypothyroidism $[188,189]$.

With regard to other conditions, renal insufficiency can lead to moderate hyperprolactinaemia [190, 191], and there are exceptional cases of non-pituitary tumours secreting prolactin, for instance renal cell carcinoma, gonadoblastoma, cervical carcinoma, nonHodgkin lymphoma, and colorectal adenocarcinoma [192-196]. In generally healthy subjects, pregnancy, breastfeeding, stress, exercise, and sleep can cause prolactin elevation [197]. Iatrogenic hyperprolactinaemia can also occur (Table 1). For instance, risperidone and metoclopramide medication can lead to prolactin levels above $200 \mu \mathrm{g} / \mathrm{L}$ [198, 199]. Medication-related hyperprolactinaemia has been reported at $31 \%$ in patients treated with neuroleptics, $28 \%$ in those treated with neuroleptic-like drugs, $26 \%$ in patients treated with antidepressants, and $5 \%$ in patients taking H2-receptor antagonists [200]. In such cases of druginduced hyperprolactinaemia, prolactin elevation is usually mild but can be highly variable [201].

It is recommended, therefore, that diagnostic work-up includes assessment of TSH, free thyroxine (FT4), and creatinine levels to exclude secondary causes of hyperprolactinaemia. Many patients with hyperprolactinaemia have a predominance of high-molecular-weight prolactin (macroprolactinaemia) [202]. Most of these patients have unimpaired fertility and uneventful pregnancies, although they may present with some of the usual symptoms of hyperprolactinaemia such as galactorrhoea or menstrual disorders [202-204]. Patients with macroprolactinaemia generally do not require treatment, but the diagnosis is complicated by the fact that prolactin levels are highly variable and overlap with those found in patients with monomeric hyperprolactinaemia [205]. The diagnostic protocol for macroprolactinaemia should be included in the laboratory work-up for patients with 
Table 1 Pharmacological causes of hyperprolactinaemia [182]

\begin{tabular}{ll}
\hline Pharmacological group & Drugs \\
\hline Antipsychotics & Typical: phenothiazines, butirophenones, thyoxanthenes \\
Antidepressants & Atypical: risperidone, molindone, amisulpride, quetiapine, olanzapine \\
& Tricyclics: amitriptyline, desipramine, clomipramine \\
& MAO inhibitors: pargyline, clorgyline \\
Antihypertensive drugs & SSRls: fluoxetine, citalopram, paroxetine \\
Anticonvulsants & Verapamil, a-methyldopa, reserpine, labetolol \\
Prokinetics & Phenytoin \\
Hormonal preparations & Metoclopramide, domperidone \\
H2-blockers & Oestrogen, danazol \\
Controlled substances & Cimetidine, ranitidine \\
Other & Opiates, methadone, morphine, apomorphine, heroin, cocaine, marijuana \\
\hline
\end{tabular}

$M A O$ monoamine oxidase, SSRI selective serotonin reuptake inhibitor

hyperprolactinaemia, to spare patients from unnecessary hormonal or radiological investigations and treatments.

\section{Consequences of delayed diagnosis}

Bone loss and vertebral fractures are the most common comorbidities of hyperprolactinaemia-mediated sex-steroid attenuation [206, 207]. In particular, spinal bone density is decreased by approximately $25 \%$ in women with hyperprolactinaemia and may be permanent, although overt osteoporosis is rare [208]. Hyperprolactinaemia is an important cause of infertility in both women and men [185]. It can be reversed by appropriate treatment, for example with dopamine agonists [209, 210]. However, in some women with prolactinomas in whom hyperprolactinaemia has been corrected, two problems may potentially arise. First is the potential risk of the dopamine agonist to early fetal development, although reassuring data have been collected in pregnant women treated with bromocriptine and - in more limited cohorts - those treated with cabergoline [211]. Second, pregnancy itself may be detrimental because the increase in oestrogen levels may stimulate tumour growth [212, 213].

Although metabolic consequences of untreated hyperprolactinaemia can be expected, only limited data have been reported on the involvement of hyperprolactinaemia in the pathogenesis of obesity, glucose intolerance, and an impaired metabolic profile [214]. Importantly, treatment of prolactinoma has been shown to reduce the prevalence of metabolic syndrome and to improve the metabolic profile $[215,216]$.

\section{Pituitary thyrotroph adenomas}

Pituitary adenomas that produce TSH (TSH-omas) accounted for $0.7 \%$ of pituitary adenomas in the study by Tjörnstrand et al. giving a SIR of 0.03 per 100,000 [172]. Another Swedish study reported the national prevalence in 2010 as 2.8 per 1 million inhabitants [217].
These data support earlier epidemiological reports suggesting that thyrotroph adenomas account for between $0.5 \%$ and $2.0 \%$ of pituitary adenomas overall $[218,219]$. Unlike incidences of the other secreting pituitary adenomas, that of thyrotroph adenomas is similar in women and men [218].

Patients with TSH-omas usually present with signs and symptoms typical of hyperthyroidism, and the presence of goitre is an almost constant symptom of pituitary thyrotroph adenoma [4]. The typical features include nervousness, irritability, increased perspiration, increased heart rate, hand tremors, anxiety, difficulty sleeping, muscular weakness, frequent diarrhoea, weight loss, and oligoamenorrhoea. However, these features may be overshadowed by symptoms related to hypersecretion or deficiency of other pituitary hormones [4]. As reported in an overview by Beck-Peccoz et al. [4], dysfunction of the gonadal axis is less common than hyperthyroid features in patients with TSH-omas, but it is not rare. Menstrual disorders occur in approximately one-third of cases in females, mainly those with mixed TSH or prolactin-secreting adenomas. In males with TSH-secreting pituitary adenomas, central hypogonadism, delayed puberty, and decreased libido may manifest [4]. The predominant signs and symptoms of pituitary thyrotroph adenomas are related to expanding tumour mass, including hypopituitarism, headaches (in $20-25 \%$ of patients), and visual field defects (in $50 \%$ of patients) [4].

For biochemical diagnosis, European guidelines for the diagnosis of thyrotropin-secreting pituitary tumours recommend the measurement of circulating free triiodothyronine (FT3) and FT4 by using "two-step" methods (e.g. equilibrium dialysis and radioimmunoassay or adsorption chromatography and radioimmunoassay, with back-titration) in addition to TSH measurement for accurate differential diagnosis [220]. TSH-oma should be suspected if the patient presents with hyperthyroidism and high circulating levels of FT4 and FT3 and if TSH is 
not suppressed in thyrotropin-releasing hormone stimulation tests [220]. Serum TSH levels in patients with TSH-oma are mildly elevated or in the normal range [220]. In the context of elevated thyroid hormone levels, a normal TSH value excludes a priori peripheral thyroid disease (e.g. Graves' disease) except when there is resistance to thyroid hormones [221]. Therefore, TSH measurement is mandatory in the diagnostic procedure in case of hyperthyroidism.

\section{Considerations for accurate diagnosis}

Using the two-step methods suggested by Beck-Peccoz et al., other conditions that can result in detectable serum TSH and hyperthyroxinaemia (e.g. pregnancy, resistance to thyroid hormone [RTH], familial dysalbuminaemic hyperthyroxinaemia, and presence of $\mathrm{T} 3$ or $\mathrm{T} 4$ autoantibodies or circulating heterophilic antibodies) can be distinguished from hyperthyroidism secondary to secreting pituitary thyrotroph adenomas [4]. Differential diagnosis of pituitary thyrotroph adenomas and hyperthyroidism due to RTH syndrome can be made by using the following criteria: family history (signifies RTH not TSH-oma); pituitary lesions on imaging (signify TSH-oma); and germinal thyroid hormone receptor beta mutation (signifies RTH not TSH-oma) [4]. In cases with elevated levels of the alpha-subunit of pituitary glycoprotein hormone (a-GSU), elevated sex-hormone-binding globulin, and a high molar a-GSU:TSH ratio, TSH-oma rather than RTH can be suspected.

\section{Consequences of delayed diagnosis}

Early diagnosis and proper treatment of TSH-omas can prevent the appearance of the signs and symptoms associated with mechanical compression of the adjacent structures by the expanding tumour mass (i.e. visual field defects, headache, and hypopituitarism) [4]. In addition, accurate diagnosis prevents improper thyroid ablation in those patients with central hyperthyroidism in whom the clinical manifestations of TSH-omas would not be prevented [220].

\section{Conclusions}

Secreting pituitary adenomas are rare conditions that remain under-diagnosed. Diagnosis - particularly of acromegaly and Cushing's disease - can be challenging because healthcare professionals not dedicated to pituitary disorders may lack awareness of these diseases and may therefore neglect the "red flags" that may suggest them. The typical physical features are slow to manifest, and because patients generally present with signs and symptoms that overlap with those of conditions commonly seen in primary care, diagnosis may be missed or delayed. A long duration of active disease is associated with an increased risk of comorbidities, reduced quality of life, and increased mortality. Increasing efforts to support the early diagnosis and treatment of these diseases is warranted, and the deleterious effects of secreting pituitary adenomas should not be overlooked.

\section{Abbreviations \\ ACTH: Adrenocorticotropic hormone; a-GSU: Alpha-subunit of pituitary glycoprotein hormone; BMD: Bone mineral density; FT3: Free tri- \\ iodothyronine; FT4: Free thyroxine; GH: Growth hormone; GP: General practitioner; IGF-1: Insulin-like growth factor 1; OGTT: Oral glucose tolerance test; RTH: Resistance to thyroid hormone; SIR: Standardized incidence rate; TSH: Thyroid-stimulating hormone; UFC: Urinary free cortisol}

\section{Acknowledgements}

The authors received editorial and writing support in the preparation of this manuscript from Agnieszka Rarok, PhD, of Excerpta Medica.

\section{Funding}

Editorial and writing support in the preparation of this manuscript was funded by Novartis AG.

\section{Availability of data and materials}

Data sharing not applicable to this article as no datasets were generated or analysed.

\section{Authors' contributions}

TB and FC made substantial contributions to the conception and design of the manuscript, and were involved in drafting the manuscript and revising it critically for important intellectual content. Both authors also gave final approval of the version to be published. Both authors participated sufficiently in the work to take public responsibility for appropriate portions of the content, and agreed to be accountable for all aspects of the work in ensuring that questions related to the accuracy or integrity of any part of the work are appropriately investigated and resolved.

\section{Authors' information}

$T B, M D, P h D$, is Professor of Endocrinology at Aix-Marseille University, Head of the "ENDO" Division (endocrinology, nutrition, diabetes, and obesity) at Conception University Hospital, and leader of a research team in neuroendocrinology at the CRN2M Laboratory (Aix-Marseille University and Centre National de la Recherche Scientifique [CNRS]), all in Marseille, France.

FC, MD, PhD, is Professor of Endocrinology at Aix-Marseille University, Endocrinologist in the Department of Endocrinology at Conception University Hospital, and a member of the same team at the CRN2M Laboratory.

\section{Competing interests}

The authors declares that they have no competing interests.

\section{Consent for publication}

Not applicable.

\section{Ethics approval and consent to participate}

Not applicable.

Received: 19 May 2016 Accepted: 16 September 2016

Published online: 06 October 2016

\footnotetext{
References

1. Yamada S, Ohyama K, Taguchi M, Takeshita A, Morita K, Takano K, Sano T. A study of the correlation between morphological findings and biological activities in clinically nonfunctioning pituitary adenomas. Neurosurgery. 2007;61 (3):580-4. discussion 584-5.

2. Ntali G, Capatina C, Grossman A, Karavitaki N. Clinical review: functioning gonadotroph adenomas. J Clin Endocrinol Metab. 2014;99(12):4423-33.

3. Melmed S, Casanueva FF, Hoffman AR, Kleinberg DL, Montori VM, Schlechte JA, Wass JA, Endocrine Society. Diagnosis and treatment of hyperprolactinemia: an Endocrine Society clinical practice guideline. J Clin Endocrinol Metab. 2011;96(2):273-88.
} 
4. Beck-Peccoz P, Persani L, Lania A. Thyrotropin-secreting pituitary adenomas [Updated 2015 May 1]. In: De Groot L, Beck-Peccoz P, Chrousos G, Dungan K, Grossman A, Hershman JM, Koch C, McLachlan R, New M, Rebar R, Singer F, Vinik A, Weicker MO, editors. Endotext [Internet]. South Dartmouth: MDText.com, Inc; 2000

5. Raverot G, Wierinckx A, Dantony E, Auger C, Chapas G, Villeneuve L, Brue T, Figarella-Branger D, Roy P, Jouanneau E, Jan M, Lachuer J, Trouillas J, HYPOPRONOS. Prognostic factors in prolactin pituitary tumors: clinical, histological, and molecular data from a series of 94 patients with a long postoperative follow-up. J Clin Endocrinol Metab. 2010;95(4):1708-16.

6. Di leva A, Rotondo F, Syro LV, Cusimano MD, Kovacs K. Aggressive pituitary adenomas-diagnosis and emerging treatments. Nat Rev Endocrinol. 2014; 10(7):423-35.

7. Knosp E, Steiner E, Kitz K, Matula C. Pituitary adenomas with invasion of the cavernous sinus space: a magnetic resonance imaging classification compared with surgical findings. Neurosurgery. 1993;33(4):610-7.

8. Valette-Kasic S, Dufour H, Mugnier M, Trouillas J, Valdes-Socin H, Caron P, Morange S, Girard N, Grisoli F, Jaquet P, Brue T. Markers of tumor invasion are major predictive factors for the long-term outcome of corticotroph microadenomas treated by transsphenoidal adenomectomy. Eur J Endocrinol. 2000;143(6):761-8.

9. Trouillas J, Roy P, Sturm N, Dantony E, Cortet-Rudelli C, Viennet G, Bonneville JF, Assaker R, Auger C, Brue T, Cornelius A, Dufour H, Jouanneau E, François P, Galland F, Mougel F, Chapuis F, Villeneuve L, Maurage CA, Figarella-Branger D, Raverot G, members of HYPOPRONOS, Barlier A, Bernier M, Bonnet F, BorsonChazot F, Brassier G, Caulet-Maugendre S, Chabre O, Chanson P, Cottier JF, Delemer B, Delgrange E, Di Tommaso L, Eimer S, Gaillard S, Jan M, Girard JJ, Lapras V, Loiseau H, Passagia JG, Patey M, Penfornis A, Poirier JY, Perrin G, Tabarin A. A new prognostic clinicopathological classification of pituitary adenomas: a multicentric case-control study of 410 patients with 8 years post-operative follow-up. Acta Neuropathol. 2013;126(1):123-35.

10. Katznelson L, Laws Jr ER, Melmed S, Molitch ME, Murad MH, Utz A, Wass JA Endocrine Society. Acromegaly: an endocrine society clinical practice guideline. J Clin Endocrinol Metab. 2014;99(11):3933-51.

11. Praw SS, Heaney AP. Medical treatment of Cushing's disease: overview and recent findings. Int J Gen Med. 2009;2:209-17.

12. Melmed S, Casanueva FF, Klibanski A, Bronstein MD, Chanson P, Lamberts SW, Strasburger CJ, Wass JA, Giustina A. A consensus on the diagnosis and treatment of acromegaly complications. Pituitary. 2013;16(3):294-302.

13. Colao A, Boscaro M, Ferone D, Casanueva FF. Managing Cushing's disease: the state of the art. Endocrine. 2014:47(1):9-20.

14. Ezzat S, Asa SL, Couldwell WT, Barr CE, Dodge WE, Vance ML, McCutcheon IE. The prevalence of pituitary adenomas: a systematic review. Cancer. 2004;101(3):613-9.

15. Krikorian A, Aron D. Evaluation and management of pituitary incidentalomas - revisiting an acquaintance. Nat Clin Pract Endocrinol Metab. 2006;2(3):138-45

16. Agustsson TT, Baldvinsdottir T, Jonasson JG, Olafsdottir $E$, Steinthorsdottir $V$, Sigurdsson G, Thorsson AV, Carroll PV, Korbonits M, Benediktsson R. The epidemiology of pituitary adenomas in Iceland, 1955-2012: a nationwide population-based study. Eur J Endocrinol. 2015;173(5):655-64.

17. Chanson P, Salenave S, Kamenicky P, Cazabat L, Young J. Pituitary tumours: acromegaly. Best Pract Res Clin Endocrinol Metab. 2009;23(5):555-74.

18. Melmed S. Acromegaly pathogenesis and treatment. J Clin Invest. 2009; 119(11):3189-202.

19. Castinetti F, Morange I, Conte-Devolx B, Brue T. Cushing's disease. Orphanet J Rare Dis. 2012:7:41.

20. Miller RE, Learned-Miller EG, Trainer P, Paisley A, Blanz V. Early diagnosis of acromegaly: computers vs clinicians. Clin Endocrinol (Oxf). 2011;75(2):226-31.

21. Schneider HJ, Kosilek RP, Günther M, Roemmler J, Stalla GK, Sievers C, Reincke M, Schopohl J, Würtz RP. A novel approach to the detection of acromegaly: accuracy of diagnosis by automatic face classification. J Clin Endocrinol Metab. 2011;96(7):2074-80.

22. Kosilek RP, Frohner R, Würtz RP, Berr CM, Schopohl J, Reincke M, Schneider $\mathrm{HJ}$. Diagnostic use of facial image analysis software in endocrine and genetic disorders: review, current results and future perspectives. Eur Endocrinol. 2015;173(4):M39-44.

23. Wagenmakers MA, Roerink SH, Maal TJ, Maal TJ, Pelleboer RH, Smit JW, Hermus AR, Bergé SJ, Netea-Maier RT, Xi T. Three-dimensional facial analysis in acromegaly: a novel tool to quantify craniofacial characteristics after long-term remission. Pituitary. 2015;18(1):126-34.
24. Cuny $T$, Pertuit M, Sahnoun-Fathallah M, Daly A, Occhi G, Odou MF, Tabarin A, Nunes ML, Delemer B, Rohmer V, Desailloud R, Kerlan V, Chabre O, Sadoul JL, Cogne M, Caron P, Cortet-Rudelli C, Lienhardt A, Raingeard I, Guedj AM, Brue T, Beckers A, Weryha G, Enjalbert A, Barlier A. Genetic analysis in young patients with sporadic pituitary macroadenomas: besides AIP don't forget MEN1 genetic analysis. Eur J Endocrinol. 2013;168(4):533-41.

25. Bex M, Abs R, T'Sjoen G, Mockel J, Velkeniers B, Muermans K, Maiter D. AcroBel - the Belgian registry on acromegaly: a survey of the 'real-life' outcome in 418 acromegalic subjects. Eur J Endocrinol. 2007;157(4):399-409.

26. Etxabe J, Gaztambide S, Latorre P, Vazquez JA. Acromegaly: an epidemiological study. J Endocrinol Invest. 1993;16(3):181-7.

27. Holdaway IM, Rajasoorya C. Epidemiology of acromegaly. Pituitary. 1999:2(1):29-41.

28. Kauppinen-Mäkelin R, Sane T, Reunanen A, Välimäki MJ, Niskanen L, Markkanen $H$, Löyttyniemi E, Ebeling T, Jaatinen $\mathrm{P}$, Laine $H$, Nuutila $\mathrm{P}$, Salmela P, Salmi J, Stenman UH, Viikari J, Voutilainen E. A nationwide survey of mortality in acromegaly. J Clin Endocrinol Metab. 2005;90(7):4081-6.

29. Mercieca C, Gruppetta M, Vassallo J. Epidemiology, treatment trends and outcomes of acromegaly. Eur J Intern Med. 2012;23(8):e206-7.

30. Ritchie CM, Atkinson AB, Kennedy AL, Lyons AR, Gordon DS, Fannin T, Hadden DR. Ascertainment and natural history of treated acromegaly in Northern Ireland. Ulster Med J. 1990;59(1):55-62.

31. Mestron A, Webb SM, Astorga R, Benito P, Catala M, Gaztambide S, Gomez JM, Halperin I, Lucas-Morante T, Moreno B, Obiols G, de Pablos P, Paramo C, Pico A, Torres E, Varela C, Vazquez JA, Zamora J, Albareda M, Gilabert M. Epidemiology, clinical characteristics, outcome, morbidity and mortality in acromegaly based on the Spanish Acromegaly Registry (Registro Español de Acromegalia, REA). Eur J Endocrinol. 2004;151(4):439-46.

32. Cannavò S, Ferraù F, Ragonese M, Curtò L, Torre ML, Magistri M, Marchese A, Alibrandi A, Trimarchi F. Increased prevalence of acromegaly in a highly polluted area. Eur J Endocrinol. 2010;163(4):509-13.

33. Fernandez A, Karavitaki N, Wass JA. Prevalence of pituitary adenomas: a community-based, cross-sectional study in Banbury (Oxfordshire, UK). Clin Endocrinol (Oxf). 2010;72(3):377-82.

34. Burton $T$, Le Nestour $E$, Neary M, Ludlam WH. Incidence and prevalence of acromegaly in a large US health plan database. Pituitary. 2016;19(3):262-7.

35. Schneider HJ, Sievers C, Saller B, Wittchen HU, Stalla GK. High prevalence of biochemical acromegaly in primary care patients with elevated IGF-1 levels. Clin Endocrinol (Oxf). 2008;69(3):432-5.

36. Arosio M, Reimondo G, Malchiodi E, Berchialla P, Borraccino A, De Marinis L, Pivonello R, Grottoli S, Losa M, Cannavò S, Minuto F, Montini M, Bondanelli M, De Menis E, Martini C, Angeletti G, Velardo A, Peri A, Faustini-Fustini M, Tita P, Pigliaru F, Borretta G, Scaroni C, Bazzoni N, Bianchi A, Appetecchia M, Cavagnini F, Lombardi G, Ghigo E, Beck-Peccoz P, Colao A, Terzolo M, Italian Study Group of Acromegaly. Predictors of morbidity and mortality in acromegaly: an Italian survey. Eur J Endocrinol. 2012;167(2):189-98.

37. Ayuk J, Clayton RN, Holder G, Sheppard MC, Stewart PM, Bates AS. Growth hormone and pituitary radiotherapy, but not serum insulin-like growth factor-I concentrations, predict excess mortality in patients with acromegaly. J Clin Endocrinol Metab. 2004;89(4):1613-7.

38. Fieffe $\mathrm{S}$, Morange I, Petrossians $\mathrm{P}$, Chanson $\mathrm{P}$, Rohmer V, Cortet $\mathrm{C}$, Borson-Chazot F, Brue T, Delemer B, French Acromegaly Registry. Diabetes in acromegaly, prevalence, risk factors, and evolution: data from the French Acromegaly Registry. Eur J Endocrinol. 2011;164(6):877-84.

39. Petersenn S, Buchfelder M, Gerbert B, Franz H, Quabbe HJ, Schulte HM, Grussendorf M, Reincke M, Participants of the German Acromegaly Register. Age and sex as predictors of biochemical activity in acromegaly: analysis of 1485 patients from the German Acromegaly Register. Clin Endocrinol (Oxf). 2009;71(3):400-5.

40. Schöfl C, Franz H, Grussendorf M, Honegger J, Jaursch-Hancke C, Mayr B, Schopohl J, Participants of the German Acromegaly Register. Long-term outcome in patients with acromegaly: analysis of 1344 patients from the German Acromegaly Register. Eur J Endocrinol. 2012;168(1):39-47.

41. Sesmilo G, Gaztambide S, Venegas E, Picó A, Del Pozo C, Blanco C, Torres E, Álvarez-Escolà C, Fajardo C, García R, Cámara R, Bernabeu I, Soto A, Villabona C, Serraclara A, Halperin I, Alcázar V, Palomera E, Webb SM, REA investigators. Changes in acromegaly treatment over four decades in Spain: analysis of the Spanish Acromegaly Registry (REA). Pituitary. 2013;16(1):115-21.

42. Colao A, Ferone D, Marzullo P, Lombardi G. Systemic complications of acromegaly: epidemiology, pathogenesis, and management. Endocr Rev. 2004;25(1):102-52. 
43. Melmed S. Medical progress: Acromegaly. N Engl J Med. 2006;355(24):2558-73.

44. Giustina A, Chanson P, Bronstein MD, Klibanski A, Lamberts S, Casanueva FF, Trainer P, Ghigo E, Ho K, Melmed S, Acromegaly Consensus Group. A consensus on criteria for cure of acromegaly. J Clin Endocrinol Metab. 2010;95(7):3141-8.

45. Petrossians $P$, Tichomirowa MA, Stevenaert A, Martin D, Daly AF, Beckers A. The Liege Acromegaly Survey (LAS): a new software tool for the study of acromegaly. Ann Endocrinol (Paris). 2012;73(3):190-201.

46. Luna AM, Wilson DM, Wibbelsman CJ, Brown RC, Nagashima RJ, Hintz RL, Rosenfeld RG. Somatomedins in adolescence: a cross-sectional study of the effect of puberty on plasma insulin-like growth factor I and II levels. J Clin Endocrinol Metab. 1983;57(2):268-71.

47. Caregaro L, Favaro A, Santonastaso P, Alberino F, Di Pascoli L, Nardi M, Favaro S, Gatta A. Insulin-like growth factor 1 (IGF-1), a nutritional marker in patients with eating disorders. Clin Nutr. 2001;20(3):251-7.

48. Livingstone $\mathrm{C}$. Insulin-like growth factor-I (IGF-I) and clinical nutrition. Clin Sci (Lond). 2013;125(6):265-80.

49. Weber MM, Auernhammer CJ, Lee PD, Engelhardt D, Zachoval R. Insulin-like growth factors and insulin-like growth factor binding proteins in adult patients with severe liver disease before and after orthotopic liver transplantation. Horm Res. 2002;57(3-4):105-12.

50. Bidlingmaier M, Friedrich N, Emeny RT, Spranger J, Wolthers OD, Roswall J, Körner A, Obermayer-Pietsch B, Hübener C, Dahlgren J, Frystyk J, Pfeiffer AF, Doering A, Bielohuby M, Wallaschofski H, Arafat AM. Reference intervals for insulin-like growth factor-1 (IGF-I) from birth to senescence: results from a multicenter study using a new automated chemiluminescence IGF-I immunoassay conforming to recent international recommendations. J Clin Endocrinol Metab. 2014;99(5):1712-21.

51. Frystyk J, Freda P, Clemmons DR. The current status of IGF-I assays - a 2009 update. Growth Horm IGF Res. 2010;20(1):8-18.

52. Clayton KL, Holly JM, Carlsson LM, Jones J, Cheetham TD, Taylor AM, Dunger DB. Loss of the normal relationships between growth hormone, growth hormone-binding protein and insulin-like growth factor-l in adolescents with insulin-dependent diabetes mellitus. Clin Endocrinol (Oxf). 1994:41(4):517-24.

53. Giustina A, Bevan JS, Bronstein MD, Casanueva FF, Chanson P, Petersenn S, Thanh XM, Sert C, Houchard A, Guillemin I, Melmed S, SAGIT Investigator Group. SAGIT: clinician-reported outcome instrument for managing acromegaly in clinical practice - development and results from a pilot study. Pituitary. 2016;19(1):39-49.

54. Pleil A, van der Lely AJ, Badia X, Brue $T$, Buchfelder M, Burman $P$, Ghigo E, Gomez R, Jorgensen JO, Luger A, van der Lans-Bussemaker J, Webb S, Strasburger C. Development of a prediction model of disease activity in support of clinical practice - the Acrodat experience. Value Health. 2015; 18(7):A708.

55. Prencipe N, Floriani I, Guaraldi F, Di Giacomo SV, Cannavo S, Arnaldi G, Berton A, Torri V, Spinello M, Arvat E, Ghigo E, Grottoli S. ACROSCORE: a new and simple tool for the diagnosis of acromegaly, a rare and underdiagnosed disease. Clin Endocrinol (Oxf). 2015;84(3):380-5.

56. Sievers C, Ising M, Pfister H, Dimopoulou C, Schneider HJ, Roemmler J, Schopohl J, Stalla GK. Personality in patients with pituitary adenomas is characterized by increased anxiety-related traits: comparison of 70 acromegalic patients with patients with non-functioning pituitary adenomas and age- and gender-matched controls. Eur J Endocrinol. 2009;160(3):367-73.

57. Akdeniz B, Gedik A, Turan O, Ozpelit E, Ikiz AO, Itil O, Badak O, Baris N, Cömlekçi A. Evaluation of left ventricular diastolic function according to new criteria and determinants in acromegaly. Int Heart J. 2012;53(5):299-305.

58. Martín-Rodríguez JF, Madrazo-Atutxa A, Venegas-Moreno E, Benito-López P, Gálvez MÁ, Cano DA, Tinahones FJ, Torres-Vela E, Soto-Moreno A, Leal-Cerro A. Neurocognitive function in acromegaly after surgical resection of $\mathrm{GH}$ secreting adenoma versus naïve acromegaly. PLoS One. 2013;8(4):e60041.

59. Colao A. Long-term acromegaly and associated cardiovascular complications: a case-based review. Best Pract Res Clin Endocrinol Metab. 2009;23 Suppl 1:S31-8

60. Golkowski F, Krzentowska-Korek A, Baldys-Waligorska A, HubalewskaDydejczyk A. Goiter, cardiovascular and metabolic disorders in patients with acromegaly. Endocr Regul. 2011:45(4):191-7.

61. Santos A, Resmini E, Martínez MA, Martí C, Ybarra J, Webb SM. Quality of life in patients with pituitary tumors. Curr Opin Endocrinol Diabetes Obes. 2009; 16(4):299-303.

62. Cannavo S, Almoto B, Cavalli G, Squadrito S, Romanello G, Vigo MT, Fiumara F, Benvenga S, Trimarchi F. Acromegaly and coronary disease: an integrated evaluation of conventional coronary risk factors and coronary calcifications detected by computed tomography. J Clin Endocrinol Metab. 2006;91(10): 3766-72.

63. Colao A, Pivonello R, Grasso LF, Auriemma RS, Galdiero M, Savastano S, Lombardi G. Determinants of cardiac disease in newly diagnosed patients with acromegaly: results of a 10 year survey study. Eur J Endocrinol. 2011; 165(5)::13-72.

64. Dekkers OM, Biermasz NR, Pereira AM, Romijn JA, Vandenbroucke JP. Mortality in acromegaly: a metaanalysis. J Clin Endocrinol Metab. 2008;93(1):61-7.

65. Orme SM, McNally RJ, Cartwright RA, Belchetz PE. Mortality and cancer incidence in acromegaly: a retrospective cohort study. United Kingdom Acromegaly Study Group. J Clin Endocrinol Metab. 1998;83(8):2730-4.

66. Trepp R, Stettler C, Zwahlen M, Seiler R, Diem P, Christ ER. Treatment outcomes and mortality of 94 patients with acromegaly. Acta Neurochir (Wien). 2005;147(3):243-51. discussion 250-1.

67. Bates AS, Van't Hoff W, Jones JM, Clayton RN. An audit of outcome of treatment in acromegaly. Q J Med. 1993;86(5):293-9.

68. Fatti LM, Scacchi M, Pincelli Al, Lavezzi E, Cavagnini F. Prevalence and pathogenesis of sleep apnea and lung disease in acromegaly. Pituitary. 2001;4(4):259-62.

69. Colao A, Marzullo P, Cuocolo A, Spinelli L, Pivonello R, Bonaduce D, Salvatore M, Lombardi G. Reversal of acromegalic cardiomyopathy in young but not in middle-aged patients after 12 months of treatment with the depot long-acting somatostatin analogue octreotide. Clin Endocrinol (Oxf). 2003;58(2):169-76.

70. Colao A, Auriemma RS, Galdiero M, Lombardi G, Pivonello R. Effects of initial therapy for five years with somatostatin analogs for acromegaly on growth hormone and insulin-like growth factor-l levels, tumor shrinkage, and cardiovascular disease: a prospective study. J Clin Endocrinol Metab. 2009;94(10):3746-56.

71. Herrmann BL, Severing M, Schmermund A, Berg C, Budde T, Erbel R, Mann K. Impact of disease duration on coronary calcification in patients with acromegaly. Exp Clin Endocrinol Diabetes. 2009;117(8):417-22.

72. Găloiu S, Jurcuț R, Vlădaia A, Florian A, Purice M, Popescu BA, Ginghină C, Coculescu M. Structural and functional changes of carotid wall properties in patients with acromegaly are not restored after 1 year of GH/IGF1 normalization. Exp Clin Endocrinol Diabetes. 2012;120(4):238-43.

73. Bassareo PP, Marras AR, Mercuro G. Adolescent acromegaly and decreased arterial distensibility despite successful treatment. Clin Endocrinol (Oxf). 2012;77(1):79-85.

74. Clemmons DR. Roles of insulin-like growth factor-I and growth hormone in mediating insulin resistance in acromegaly. Pituitary. 2002;5(3):181-3.

75. Baykan M, Erem C, Gedikli O, Hacihasanoglu A, Erdogan T, Kocak M, Kaplan $\mathrm{S}$, Korkmaz L, Celik S. Impairment in flow-mediated vasodilatation of the brachial artery in acromegaly. Med Princ Pract. 2009;18(3):228-32.

76. Ronchi CL, Varca V, Beck-Peccoz P, Orsi E, Donadio F, Baccarelli A, Giavoli C, Ferrante E, Lania A, Spada A, Arosio M. Comparison between six-year therapy with long-acting somatostatin analogs and successful surgery in acromegaly: effects on cardiovascular risk factors. J Clin Endocrinol Metab. 2006;91(1):121-8.

77. Tagliafico A, Resmini E, Ferone D, Martinoli C. Musculoskeletal complications of acromegaly: what radiologists should know about early manifestations. Radiol Med. 2011;116(5):781-92.

78. Biermasz NR, Pereira AM, Smit JWA, Romijn JA, Roelfsema F. Morbidity after long-term remission for acromegaly: persisting joint-related complaints cause reduced quality of life. J Clin Endocrinol Metab. 2005; 90(5):2731-9.

79. Claessen KMJA, Ramautar SR, Pereira AM, Smit JW, Roelfsema F, Romijn JA, Kroon HM, Kloppenburg M, Biermasz NR. Progression of acromegalic arthropathy despite long-term biochemical control: a prospective, radiological study. Eur J Endocrinol Eur Fed Endocr Soc. 2012;167(2):235-44.

80. Ruchala M, Skiba A, Gurgul E, Uruski P, Wasko R, Sowinski J. The occurrence of thyroid focal lesions and a need for fine needle aspiration biopsy in patients with acromegaly due to an increased risk of thyroid cancer. Neuro Endocrinol Lett. 2009;30(3):382-6.

81. Biermasz NR, van 't Klooster R, Wassenaar MJ, Malm SH, Claessen KM, Nelissen RG, Roelfsema F, Pereira AM, Kroon HM, Stoel BC, Romijn JA, Kloppenburg M. Automated image analysis of hand radiographs reveals widened joint spaces in patients with long-term control of acromegaly: relation to disease activity and symptoms. Eur J Endocrinol. 2012;166(3):407-13. 
82. Mazziotti G, Bianchi A, Bonadonna S, Cimino V, Patelli I, Fusco A, Pontecorvi A, De Marinis L, Giustina A. Prevalence of vertebral fractures in men with acromegaly. J Clin Endocrinol Metab. 2008;93(12):4649-55.

83. Mazziotti G, Bianchi A, Porcelli T, Mormando M, Maffezzoni F, Cristiano A, Giampietro A, De Marinis L, Giustina A. Vertebral fractures in patients with acromegaly: a 3-year prospective study. J Clin Endocrinol Metab. 2013;98(8):3402-10.

84. Mazziotti G, Biagioli E, Maffezzoni F, Spinello M, Serra V, Maroldi R, Floriani I, Giustina A. Bone turnover, bone mineral density, and fracture risk in acromegaly: a meta-analysis. J Clin Endocrinol Metab. 2015;100(2):384-94.

85. Bonadonna S, Mazziotti G, Nuzzo M, Bianchi A, Fusco A, De Marinis L, Giustina A. Increased prevalence of radiological spinal deformities in active acromegaly: a cross-sectional study in postmenopausal women. J Bone Miner Res. 2005;20(10):1837-44

86. Claessen KMJA, Kroon HM, Pereira AM, Appelman-Dijkstra NM, Verstegen MJ, Kloppenburg M, Hamdy NA, Biermasz NR. Progression of vertebral fractures despite long-term biochemical control of acromegaly: a prospective follow-up study. J Clin Endocrinol Metab. 2013;98(12):4808-15.

87. Davi' MV, Dalle Carbonare L, Giustina A, Ferrari M, Frigo A, Lo Cascio V, Francia G. Sleep apnoea syndrome is highly prevalent in acromegaly and only partially reversible after biochemical control of the disease. Eur J Endocrinol Eur Fed Endocr Soc. 2008;159(5):533-40.

88. Akkoyunlu ME, Ilhan MM, Bayram M, Taşan E, Yakar F, Ozçelik HK, Karakose F, Kart L. Does hormonal control obviate positive airway pressure therapy in acromegaly with sleep-disordered breathing? Respir Med. 2013;107(11): 1803-9.

89. Berg C, Wessendorf TE, Mortsch F, Forsting M, Teschler $H$, Weischer T, Mann K, Saller B, Herrmann BL. Influence of disease control with pegvisomant on sleep apnoea and tongue volume in patients with active acromegaly. Eur J Endocrinol Eur Fed Endocr Soc. 2009;161(6):829-35.

90. Herrmann BL, Wessendorf TE, Ajaj W, Kahlke S, Teschler H, Mann K. Effects of octreotide on sleep apnoea and tongue volume (magnetic resonance imaging) in patients with acromegaly. Eur J Endocrinol Eur Fed Endocr Soc. 2004;151(3):309-15.

91. Leon-Carrion J, Martin-Rodriguez JF, Madrazo-Atutxa A, Soto-Moreno A, Venegas-Moreno E, Torres-Vela E, Benito-López P, Gálvez MA, Tinahones FJ, Leal-Cerro A. Evidence of cognitive and neurophysiological impairment in patients with untreated naive acromegaly. J Clin Endocrinol Metab. 2010; 95(9):4367-79

92. Baris D, Gridley G, Ron E, Weiderpass E, Mellemkjaer L, Ekbom A, Olsen JH, Baron JA, Fraumeni Jr JF. Acromegaly and cancer risk: a cohort study in Sweden and Denmark. Cancer Causes Control. 2002;13(5):395-400.

93. Kauppinen-Mäkelin R, Sane T, Välimäki MJ, Markkanen H, Niskanen L, Ebeling T, Jaatinen P, Juonala M, Finnish Acromegaly Study Group. Increased cancer incidence in acromegaly - a nationwide survey. Clin Endocrinol (Oxf). 2010; 72(2):278-9.

94. Jenkins PJ. Acromegaly and cancer. Horm Res. 2004;62 Suppl 1:108-15.

95. Renehan AG, O'Connell J, O'Halloran D, Shanahan F, Potten CS, O'Dwyer ST, Shalet SM. Acromegaly and colorectal cancer: a comprehensive review of epidemiology, biological mechanisms, and clinical implications. Horm Metab Res. 2003;35(11-12):712-25.

96. Petroff D, Tönjes A, Grussendorf M, Droste M, Dimopoulou C, Stalla G, Jaursch-Hancke C, Mai M, Schopohl J, Schöfl C. The incidence of cancer among acromegaly patients: results from the German Acromegaly Registry. J Clin Endocrinol Metab. 2015;100(10):3894-902.

97. Tita P, Ambrosio MR, Scolio C, Carta A, Gangemi P, Bondanelli M, Vigneri R, Degli Uberti EC, Pezzino V. High prevalence of differentiated thyroid carcinoma in acromegaly. Clin Endocrinol (Oxf). 2005;63(2):161-7.

98. Gullu BE, Celik O, Gazioglu N, Kadioglu P. Thyroid cancer is the most common cancer associated with acromegaly. Pituitary. 2010;13(3):242-8.

99. Gasperi M, Martino E, Manetti L, Arosio M, Porretti S, Faglia G, Mariotti S, Colao AM, Lombardi G, Baldelli R, Camanni F, Liuzzi A, Acromegaly Study Group of the Italian Society of Endocrinology. Prevalence of thyroid diseases in patients with acromegaly: results of an Italian multicenter study. J Endocrinol Invest. 2002;25(3):240-5.

100. Etxabe J, Vazquez JA. Morbidity and mortality in Cushing's disease: an epidemiological approach. Clin Endocrinol (Oxf). 1994;40(4):479-84.

101. Lindholm J, Juul S, Jørgensen JO, Astrup J, Bjerre P, Feldt-Rasmussen U, Hagen C, Jørgensen J, Kosteljanetz M, Kristensen L, Laurberg P, Schmidt K, Weeke J. Incidence and late prognosis of Cushing's syndrome: a population-based study. J Clin Endocrinol Metab. 2001;86(1):117-23.
102. Invitti C, Pecori Giraldi F, de Martin M, Cavagnini F. Diagnosis and management of Cushing's syndrome: results of an Italian multicentre study. Study Group of the Italian Society of Endocrinology on the Pathophysiology of the Hypothalamic-Pituitary-Adrenal Axis. J Clin Endocrinol Metab. 1999; 84(2):440-8

103. Valassi E, Santos A, Yaneva M, Tóth M, Strasburger CJ, Chanson P, Wass JA, Chabre O, Pfeifer M, Feelders RA, Tsagarakis S, Trainer PJ, Franz H, Zopf K, Zacharieva S, Lamberts SW, Tabarin A, Webb SM, ERCUSYN Study Group. The European Registry on Cushing's syndrome: 2-year experience. Baseline demographic and clinical characteristics. Eur J Endocrinol. 2011;165(3):383-92.

104. Alexandraki Kl, Kaltsas GA, Vouliotis Al, Papaioannou TG, Trisk L, Zilos A, Korbonits M, Besser GM, Anastasakis A, Grossman AB. Specific electrocardiographic features associated with Cushing's disease. Clin Endocrinol (Oxf). 2011;74(5):558-64.

105. Alexandraki KI, Kaltsas GA, Isidori AM, Akker SA, Drake WM, Chew SL, Monson JP, Besser GM, Grossman AB. The prevalence and characteristic features of cyclicity and variability in Cushing's disease. Eur J Endocrinol. 2009;160(6):1011-8.

106. Assié G, Bahurel H, Coste J, Silvera S, Kujas M, Dugué MA, Karray F, Dousset B, Bertherat J, Legmann P, Bertagna X. Corticotroph tumor progression after adrenalectomy in Cushing's disease: a reappraisal of Nelson's syndrome. J Clin Endocrinol Metab. 2007;92(1):172-9.

107. Clayton RN, Raskauskiene D, Reulen RC, Jones PW. Mortality and morbidity in Cushing's disease over 50 years in Stoke-on-Trent, UK: audit and metaanalysis of literature. J Clin Endocrinol Metab. 2011;96(3):632-42.

108. Gil-Cárdenas A, Herrera MF, Díaz-Polanco A, Rios JM, Pantoja JP. Nelson's syndrome after bilateral adrenalectomy for Cushing's disease. Surgery. 2007; 141(2):147-51.

109. Newell-Price J, Trainer P, Besser M, Grossman A. The diagnosis and differential diagnosis of Cushing's syndrome and pseudo-Cushing's states. Endocr Rev. 1998;19(5):647-72.

110. Ntali G, Asimakopoulou A, Siamatras T, Komninos J, Vassiliadi D, Tzanela M, Tsagarakis S, Grossman AB, Wass JA, Karavitaki N. Mortality in Cushing's syndrome: systematic analysis of a large series with prolonged follow-up. Eur J Endocrinol. 2013;169(5):715-23.

111. Pecori Giraldi F, Moro M, Cavagnini F, Study Group on the HypothalamoPituitary-Adrenal Axis of the Italian Society of Endocrinology. Gender-related differences in the presentation and course of Cushing's disease. J Clin Endocrinol Metab. 2003;88(4):1554-8.

112. Storr HL, Alexandraki Kl, Martin L, Isidori AM, Kaltsas GA, Monson JP, Besser GM, Matson M, Evanson J, Afshar F, Sabin I, Savage MO, Grossman AB. Comparisons in the epidemiology, diagnostic features and cure rate by transsphenoidal surgery between paediatric and adult-onset Cushing's disease. Eur J Endocrinol. 2011;164(5):667-74.

113. Stuijver DJ, van Zaane B, Feelders RA, Debeij J, Cannegieter SC, Hermus AR, van den Berg G, Pereira AM, de Herder WW, Wagenmakers MA, Kerstens MN Zelissen PM, Fliers E, Schaper N, Drent ML, Dekkers OM, Gerdes VE. Incidence of venous thromboembolism in patients with Cushing's syndrome: a multicenter cohort study. J Clin Endocrinol Metab. 2011;96(11):3525-32.

114. Witek P, Zieliński G, Szamotulska K, Witek J, Zgliczyński W. Complications of Cushing's disease - prospective evaluation and clinical characteristics. Do they affect the efficacy of surgical treatment? Endokrynol Pol. 2012;63(4):277-85.

115. Yaneva M, Kalinov K, Zacharieva S. Mortality in Cushing's syndrome: data from 386 patients from a single tertiary referral center. Eur J Endocrinol. 2013;169(5):621-7.

116. Lake MG, Krook LS, Cruz SV. Pituitary adenomas: an overview. Am Fam Physician. 2013:88(5):319-27.

117. Guaraldi F, Salvatori R. Cushing syndrome: maybe not so uncommon of an endocrine disease. J Am Board Fam Med. 2012;25(2):199-208.

118. Holsboer F. The corticosteroid receptor hypothesis of depression. Neuropsychopharmacology. 2000;23(5):477-501.

119. Trifanescu R, Carsote M, Caragheorgheopol A, Hortopan D, Dumitrascu A, Dobrescu M, Poiana C. Screening for secondary endocrine hypertension in young patients. Maedica (Buchar). 2013;8(2):108-15.

120. Cosci F, Fava GA, Sonino N. Mood and anxiety disorders as early manifestations of medical illness: a systematic review. Psychother Psychosom. 2015;84(1):22-9.

121. Murakami H, Nigawara T, Sakihara S, Kageyama K, Yamashita M, Matsuki K, Tanabe J, Matsui J, Tamasawa N, Suda T. The frequency of type 2 diabetic patients who meet the endocrinological screening criteria of subclinical Cushing's disease. Endocr J. 2010;57(3):267-72. 
122. Nieman LK. Cushing's syndrome: update on signs, symptoms and biochemical screening. Eur J Endocrinol. 2015;173(4):M33-8.

123. Pivonello R, De Leo M, Cozzolino A, Colao A. Treatment of Cushing's disease. Endocr Rev. 2015;36(4):385-486

124. Pivonello R, Isidori AM, De Martino MC, Newell-Price J, Biller BM, Colao A. Complications of Cushing's syndrome: state of the art. Lancet Diabetes Endocrinol. 2016;4(7):611-29.

125. Nieman LK, Biller BM, Findling JW, Newell-Price J, Savage MO, Stewart PM, Montori VM. The diagnosis of Cushing's syndrome: an Endocrine Society clinical practice guideline. J Clin Endocrinol Metab. 2008;93(5):1526-40.

126. Nieman LK. Update on subclinical Cushing's syndrome. Curr Opin Endocrinol Diabetes Obes. 2015;22(3):180-4.

127. Psaras T, Milian M, Hattermann V, Freiman T, Gallwitz B, Honegger J. Demographic factors and the presence of comorbidities do not promote early detection of Cushing's disease and acromegaly. Exp Clin Endocrinol Diabetes. 2011;119(1):21-5.

128. Pecori Giraldi F. Recent challenges in the diagnosis of Cushing's syndrome. Horm Res. 2009;71 Suppl 1:123-7.

129. Morris DG, Grossman AB. Dynamic tests in the diagnosis and differential diagnosis of Cushing's syndrome. J Endocrinol Invest. 2003;26(7 Suppl):64-73.

130. Alwani RA, Schmit Jongbloed LW, de Jong FH, van der Lely AJ, de Herder WW, Feelders RA. Differentiating between Cushing's disease and pseudoCushing's syndrome: comparison of four tests. Eur J Endocrinol. 2014;170(4): 477-86

131. Androulakis II, Kaltsas G, Chrousos. Pseudo-Cushing's states. In: De Groot LJ, Chrousos G, Dungan K, Grossman A, Hershman JM, Koch C, Korbonits M, McLachlan R, New M, Purnell J, Rebar R, Singer F, Vinik A, editors. Endotext [Internet]. South Dartmouth, MA: MDText.com, Inc.; 2000-2015.

132. Elamin MB, Murad MH, Mullan R, Erickson D, Harris K, Nadeem S, Ennis R, Erwin PJ, Montori VM. Accuracy of diagnostic tests for Cushing's syndrome: a systematic review and metaanalyses. J Clin Endocrinol Metab. 2008;93(5): 1553-62.

133. Raff H. Update on late-night salivary cortisol for the diagnosis of Cushing's syndrome: methodological considerations. Endocrine. 2013;44(2):346-9.

134. Vassiliadi D, Tsagarakis S. Unusual causes of Cushing's syndrome. Arq Bras Endocrinol Metabol. 2007:51(8):1245-52.

135. Carroll TB, Findling JW. Cushing's syndrome of nonpituitary causes. Curr Opin Endocrinol Diabetes Obes. 2009;16(4):308-15.

136. Foisy MM, Yakiwchuk EM, Chiu I, Singh AE. Adrenal suppression and Cushing's syndrome secondary to an interaction between ritonavir and fluticasone: a review of the literature. HIV Med. 2008;9(6):389-96.

137. Lo J, Grinspoon SK. Adrenal function in HIV infection. Curr Opin Endocrinol Diabetes Obes. 2010;17(3):205-9.

138. Bernecker C, West TB, Mansmann G, Scherbaum WA, Willenberg HS. Hypercortisolism caused by ritonavir associated inhibition of CYP 3A4 under inhalative glucocorticoid therapy. 2 case reports and a review of the literature. Exp Clin Endocrinol Diabetes. 2012;120(3):125-7.

139. Levin C, Maibach HI. Topical corticosteroid-induced adrenocortical insufficiency: clinical implications. Am J Clin Dermatol. 2002;3(3):141-7.

140. Coureau B, Bussières JF, Tremblay S. Cushing's syndrome induced by misuse of moderate- to high-potency topical corticosteroids. Ann Pharmacother. 2008;42(12):1903-7.

141. Tempark T, Phatarakijnirund V, Chatproedprai S, Watcharasindhu S, Supornsilchai V, Wananukul S. Exogenous Cushing's syndrome due to topical corticosteroid application: case report and review literature. Endocrine. 2010;38(3):328-34.

142. Webb SM, Badia X, Barahona MJ, Colao A, Strasburger CJ, Tabarin A, van Aken MO, Pivonello R, Stalla G, Lamberts SW, Glusman JE. Evaluation of health-related quality of life in patients with Cushing's syndrome with a new questionnaire. Eur J Endocrinol. 2008;158(5):623-30.

143. Graversen D, Vestergaard P, Stochholm K, Gravholt CH, Jørgensen JO. Mortality in Cushing's syndrome: a systematic review and meta-analysis. Eur J Intern Med. 2012;23(3):278-82.

144. Dekkers OM, Horváth-Puhó E, Jørgensen JO, Cannegieter SC, Ehrenstein V, Vandenbroucke JP, Pereira AM, Sørensen HT. Multisystem morbidity and mortality in Cushing's syndrome: a cohort study. J Clin Endocrinol Metab. 2013;98(6):2277-84.

145. Dekkers OM, Biermasz NR, Pereira AM, Roelfsema F, van Aken MO, Voormolen JH, Romijn JA. Mortality in patients treated for Cushing's disease is increased, compared with patients treated for nonfunctioning pituitary macroadenoma. J Clin Endocrinol Metab. 2007;92(3):976-81.
146. Lambert JK, Goldberg L, Fayngold S, Kostadinov J, Post KD, Geer EB. Predictors of mortality and long-term outcomes in treated Cushing's disease: a study of 346 patients. J Clin Endocrinol Metab. 2013;98(3):1022-30.

147. Tauchmanovà L, Pivonello R, Di Somma C, Rossi R, De Martino MC, Camera L, Klain M, Salvatore M, Lombardi G, Colao A. Bone demineralization and vertebral fractures in endogenous cortisol excess: role of disease etiology and gonadal status. J Clin Endocrinol Metab. 2006;91(5):1779-84.

148. Feelders RA, Hofland LJ. Medical treatment of Cushing's disease. J Clin Endocrinol Metab. 2013;98(2):425-38.

149. Colao A, Pivonello R, Spiezia S, Faggiano A, Ferone D, Filippella M, Marzullo $P$, Cerbone G, Siciliani M, Lombardi G. Persistence of increased cardiovascular risk in patients with Cushing's disease after five years of successful cure. J Clin Endocrinol Metab. 1999:84(8):2664-72.

150. Faggiano A, Pivonello R, Spiezia S, De Martino MC, Filippella M, Di Somma C, Lombardi G, Colao A. Cardiovascular risk factors and common carotid artery caliber and stiffness in patients with Cushing's disease during active disease and 1 year after disease remission. J Clin Endocrinol Metab. 2003; 88(6):2527-33

151. Mancini T, Kola B, Mantero F, Boscaro M, Arnaldi G. High cardiovascular risk in patients with Cushing's syndrome according to $1999 \mathrm{WHO} / \mathrm{ISH}$ guidelines. Clin Endocrinol (Oxf). 2004:61(6):768-77.

152. Espinosa-de-Los-Monteros AL, Sosa E, Martinez N, Mercado M. Persistence of Cushing's disease symptoms and comorbidities after surgical cure: a long-term, integral evaluation. Endocr Pract. 2013;19(2): 252-8.

153. Terzolo M, Allasino B, Pia A, Peraga G, Daffara F, Laino F, Ardito A, Termine A, Paccotti P, Berchialla P, Migliaretti G, Reimondo G. Surgical remission of Cushing's syndrome reduces cardiovascular risk. Eur J Endocrinol. 2014; 171(1):127-36.

154. Neary NM, Booker OJ, Abel BS, Matta JR, Muldoon N, Sinaii N, Pettigrew RI, Nieman LK, Gharib AM. Hypercortisolism is associated with increased coronary arterial atherosclerosis: analysis of noninvasive coronary angiography using multidetector computerized tomography. J Clin Endocrinol Metab. 2013:98(5):2045-52.

155. van Zaane B, Nur E, Squizzato A, Dekkers OM, Twickler MT, Fliers E, Gerdes VE, Büller HR, Brandjes DP. Hypercoagulable state in Cushing's syndrome: a systematic review. J Clin Endocrinol Metab. 2009;94(8):2743-50

156. Kastelan D, Dusek T, Kraljevic I, Aganovic I. Hypercoagulable state in Cushing's syndrome is reversible following remission. Clin Endocrinol (Oxf). 2013;78(1):102-6.

157. Ferraù F, Korbonits M. Metabolic comorbidities in Cushing's syndrome Eur J Endocrinol. 2015;173(4):M133-57.

158. Geer EB, Shen W, Strohmayer E, Post KD, Freda PU. Body composition and cardiovascular risk markers after remission of Cushing's disease: a prospective study using whole-body MRI. J Clin Endocrinol Metab. 2012 97(5):1702-11.

159. Ragnarsson O, Glad CA, Bergthorsdottir R, Almqvist EG, Ekerstad E, Widell H, Wängberg B, Johannsson G. Body composition and bone mineral density in women with Cushing's syndrome in remission and the association with common genetic variants influencing glucocorticoid sensitivity. Eur J Endocrinol. 2015:172(1):1-10.

160. Greenman Y. Management of dyslipidemia in Cushing's syndrome. Neuroendocrinology. 2010:92 Suppl 1:91-5.

161. Ragnarsson O, Johannsson G. Cushing's syndrome: a structured short- and long-term management plan for patients in remission. Eur J Endocrinol. 2013;169(5):R139-52

162. Trementino L, Appolloni G, Ceccoli L, Marcelli G, Concettoni C, Boscaro M, Arnaldi G. Bone complications in patients with Cushing's syndrome: looking for clinical, biochemical, and genetic determinants. Osteoporos Int. 2014; 25(3):913-21.

163. Mazziotti G, Delgado A, Maffezzoni F, Formenti A, Giustina A. Skeletal fragility in endogenous hypercortisolism. Front Horm Res. 2016;46:66-73.

164. Vestergaard P, Lindholm J, Jørgensen JO, Hagen C, Hoeck HC, Laurberg P, Rejnmark L, Brixen K, Kristensen LØ, Feldt-Rasmussen U, Mosekilde L. Increased risk of osteoporotic fractures in patients with Cushing's syndrome. Eur J Endocrinol. 2002;146(1):51-6.

165. Andela CD, van Haalen FM, Ragnarsson O, Papakokkinou E, Johannsson G, Santos A, Webb SM, Biermasz NR, van der Wee NJ, Pereira AM. Cushing's syndrome causes irreversible effects on the human brain: a systematic review of structural and functional magnetic resonance imaging studies. Eur J Endocrinol. 2015;173(1):R1-14 
166. Langenecker SA, Weisenbach SL, Giordani B, Briceño EM, Guidotti Breting LM, Schallmo MP, Leon HM, Noll DC, Zubieta JK, Schteingart DE, Starkman MN. Impact of chronic hypercortisolemia on affective processing. Neuropharmacology. 2012;62(1):217-25.

167. Tiemensma J, Biermasz NR, Middelkoop HA, van der Mast RC, Romijn JA, Pereira AM. Increased prevalence of psychopathology and maladaptive personality traits after long-term cure of Cushing's disease. J Clin Endocrinol Metab. 2010;95(10):E129-41.

168. Pekic S, Stojanovic M, Popovic V. Contemporary issues in the evaluation and management of pituitary adenomas. Minerva Endocrinol. 2015:40(4):307-19.

169. Maiter D, Delgrange E. Therapy of endocrine disease: the challenges in managing giant prolactinomas. Eur J Endocrinol. 2014;170(6):R213-27.

170. Orphanet. Prolactinoma. Available at www.orpha.net/consor/cgi-bin/OC Exp.php?Expert=2965. Last updated February 2014. Accessed 14 Oct 2015.

171. Colao A. Pituitary tumours: the prolactinoma. Best Pract Res Clin Endocrinol Metab. 2009;23(5):575-96.

172. Tjörnstrand A, Gunnarsson K, Evert M, Holmberg E, Ragnarsson O, Rosén T, Filipsson $\mathrm{NH}$. The incidence rate of pituitary adenomas in western Sweden for the period 2001-2011. Eur J Endocrinol. 2014;171(4):519-26.

173. Raappana A, Koivukangas J, Ebeling T, Pirilä T. Incidence of pituitary adenomas in Northern Finland in 1992-2007. J Clin Endocrinol Metab. 2010;95(9):4268-75.

174. Daly AF, Rixhon M, Adam C, Dempegioti A, Tichomirowa MA, Beckers A. High prevalence of pituitary adenomas: a cross-sectional study in the province of Liege, Belgium. J Clin Endocrinol Metab. 2006;91(12):4769-75.

175. Ciccarelli A, Daly AF, Beckers A. The epidemiology of prolactinomas. Pituitary. 2005;8(1):3-6.

176. Gillam MP, Molitch ME, Lombardi G, Colao A. Advances in the treatment of prolactinomas. Endocr Rev. 2006;27(5):485-534.

177. Klibanski A. Clinical practice. Prolactinomas. N Engl J Med. 2010;362(13):1219-26.

178. Schlechte JA. Clinical practice. Prolactinoma. N Engl J Med. 2003;349(21): 2035-41.

179. Casanueva FF, Molitch ME, Schlechte JA, Abs R, Bonert V, Bronstein MD, Brue T, Cappabianca P, Colao A, Fahlbusch R, Fideleff H, Hadani M, Kelly P, Kleinberg D, Laws E, Marek J, Scanlon M, Sobrinho LG, Wass JA, Giustina A. Guidelines of the Pituitary Society for the Diagnosis and Management of Prolactinomas. Clin Endocrinol (Oxf). 2006;65(2):265-73.

180. Brue T, Delemer B, French Society of Endocrinology (SFE) work group on the consensus on hyperprolactinemia. Diagnosis and management of hyperprolactinemia: expert consensus - French Society of Endocrinology. Ann Endocrinol (Paris). 2007;68(1):58-64.

181. Vilar L, Freitas MC, Naves LA, Casulari LA, Azevedo M, Montenegro Jr R, Barros Al, Faria M, Nascimento GC, Lima JG, Nóbrega LH, Cruz TP, Mota A, Ramos A, Violante A, Lamounier Filho A, Gadelha MR, Czepielewski MA, Glezer A, Bronstein MD. Diagnosis and management of hyperprolactinemia: results of a Brazilian multicentre study with 1234 patients. J Endocrinol Invest. 2008;31(5):436-44.

182. Vilar $L$, Fleseriu M, Bronstein MD. Challenges and pitfalls in the diagnosis of hyperprolactinemia. Arq Bras Endocrinol Metab. 2014;58(1):9-22.

183. Vance ML, Thorner MO. Prolactinomas. Endocrinol Metab Clin North Am. 1987;16(3):731-53.

184. Kleinberg DL, Noel GL, Frantz AG. Galactorrhea: a study of 235 cases, including 48 with pituitary tumors. N Engl J Med. 1977;296(11):589-600.

185. Molitch ME, Reichlin S. Hyperprolactinemic disorders. Dis Mon. 1982;28(9):1-58.

186. Kawaguchi T, Ogawa Y, Tominaga T. Diagnostic pitfalls of hyperprolactinemia: the importance of sequential pituitary imaging. BMC Res Notes. 2014;7:555.

187. Andreeva M, Georgiev T, Bosadjieva E, Karagiosov L, Karagiosov K, Tomova A, Matrosov P, Kirilov G, Diankov L, Christova T. A clinicomorphological study of pituitary tumors associated with the clinical syndrome of acromegaly. Exp Clin Endocrinol. 1991;98(3):223-7.

188. Honbo KS, Herle AJV, Kellett KA. Serum prolactin levels in untreated primary hypothyroidism. Am J Med. 1978;64(5):782-7.

189. Hekimsoy Z, Kafesçiler S, Güçlü F, Ozmen B. The prevalence of hyperprolactinemia in overt and subclinical hypothyroidism. Endocr J. 2010; 57(12):1011-5.

190. Hou SH, Grossman S, Molitch ME. Hyperprolactinemia in patients with renal insufficiency and chronic renal failure requiring hemodialysis or chronic ambulatory peritoneal dialysis. Am J Kidney Dis. 1985;6(4):245-9.
191. Lim VS, Kathpalia SC, Frohman LA. Hyperprolactinemia and impaired pituitary response to suppression and stimulation in chronic renal failure: reversal after transplantation. J Clin Endocrinol Metab. 1979;48(1):101-7.

192. Stanisic TH, Donovan J. Prolactin secreting renal cell carcinoma. J Urol. 1986;136(1):85-6.

193. Hoffman WH, Gala RR, Kovacs K, Subramanian MG. Ectopic prolactin secretion from a gonadoblastoma. Cancer. 1987;60(11):2690-5.

194. Hsu CT, Yu MH, Lee CY, Jong HL, Yeh MY. Ectopic production of prolactin in uterine cervical carcinoma. Gynecol Oncol. 1992;44(2):166-71.

195. Arbaiza D, Noriega K, Marcial J, Wachtel A, Perez C, Torres CF. Ectopic production of prolactin in an infant with non-Hodgkin lymphoma. Med Pediatr Oncol. 1999;32(4):311-2.

196. Bhatavdekar JM, Patel DD, Chikhlikar PR, Shah NG, Vora HH, Ghosh N, Trived TI. Ectopic production of prolactin by colorectal adenocarcinoma. Dis Colon Rectum. 2001;44(1):119-27.

197. Melmed S, Kleinberg D. Anterior pituitary. In: Kronenberg HM, Melmed S, Polonsky KS, Larsen PR, editors. Williams Textbook of Endocrinology. 11th ed. Philadelphia: Saunders Elsevier; 2008. p. 185-261.

198. Kearns AE, Goff DC, Hayden DL, Daniels GH. Risperidone-associated hyperprolactinemia. Endocr Pract. 2000;6(6):425-9.

199. Robinson OP. Metoclopramide - side effects and safety. Postgrad Med J. 1973;49 Suppl 4:77-80.

200. Petit A, Piednoir D, Germain ML, Trenque T. Drug-induced hyperprolactinemia: a case-non-case study from the national pharmacovigilance database. Therapie. 2003;58(2):159-63.

201. Molitch ME. Drugs and prolactin. Pituitary. 2008;11(2):209-18.

202. Vallette-Kasic S, Morange-Ramos I, Selim A, Gunz G, Morange S, Enjalbert A, Martin PM, Jaquet P, Brue T. Macroprolactinemia revisited: a study on 106 patients. J Clin Endocrinol Metab. 2002;87(2):581-8.

203. Whittaker PG, Wilcox T, Lind T. Maintained fertility in a patient with hyperprolactinemia due to big, big prolactin. J Clin Endocrinol Metab. 1981; 53(4):863-6

204. Leite V, Cosby H, Sobrinho LG, Fresnoza MA, Santos MA, Friesen HG. Characterization of big, big prolactin in patients with hyperprolactinemia. Clin Endocrinol (Oxf). 1992;37(4):365-72.

205. Smith TP, Suliman AM, Fahie-Wilson MN, McKenna TJ. Gross variability in the detection of prolactin in sera containing big big prolactin (macroprolactin) by commercial immunoassays. J Clin Endocrinol Metab. 2002;87(12):5410-5.

206. Mazziotti G, Porcelli T, Mormando M, De Menis E, Bianchi A, Mejia C, Mancini T, De Marinis L, Giustina A. Vertebral fractures in males with prolactinoma. Endocrine. 2011;39(3):288-93.

207. Mazziotti G, Mancini T, Mormando M, De Menis E, Bianchi A, Doga M, Porcelli T, Vescovi PP, De Marinis L, Giustina A. High prevalence of radiological vertebral fractures in women with prolactin-secreting pituitary adenomas. Pituitary. 2011;14(4):299-306.

208. Schlechte J, el-Khoury G, Kathol M, Walkner L. Forearm and vertebral bone mineral in treated and untreated hyperprolactinemic amenorrhea. J Clin Endocrinol Metab. 1987;64(5):1021-6.

209. Ferrari C, Paracchi A, Mattei AM, de Vincentiis S, D'Alberton A, Crosignani P. Cabergoline in the long-term therapy of hyperprolactinemic disorders. Acta Endocrinol (Copenh). 1992;126(6):489-94.

210. Colao A, Vitale G, Cappabianca P, Briganti F, Ciccarelli A, De Rosa M, Zarrilli $\mathrm{S}$, Lombardi G. Outcome of cabergoline treatment in men with prolactinoma: effects of a 24-month treatment on prolactin levels, tumor mass, recovery of pituitary function, and semen analysis. J Clin Endocrinol Metab. 2004;89(4):1704-11.

211. Molitch ME. Endocrinology in pregnancy: management of the pregnant patient with a prolactinoma. Eur J Endocrinol. 2015;172(5):R205-13.

212. Glezer A, Bronstein MD. Prolactinomas, cabergoline, and pregnancy. Endocrine. 2014:47:64-9.

213. Molitch ME. Prolactinoma in pregnancy. Best Pract Res Clin Endocrinol Metab. 2011:25(6):885-96.

214. Bernabeu I, Casanueva FF. Metabolic syndrome associated with hyperprolactinemia: a new indication for dopamine agonist treatment? Endocrine. 2013;44(2):273-4.

215. Auriemma RS, Granieri L, Galdiero M, Simeoli C, Perone Y, Vitale P, Pivonello C, Negri M, Mannarino T, Giordano C, Gasperi M, Colao A, Pivonello R. Effect of cabergoline on metabolism in prolactinomas. Neuroendocrinology. 2013; 98(4):299-310.

216. Auriemma RS, Galdiero M, Vitale P, Granieri L, Lo Calzo F, Salzano C, Ferreri L, Pivonello C, Cariati F, Coppola G, de Angelis C, Colao A, Pivonello R. Effect 
of chronic cabergoline treatment and testosterone replacement on metabolism in male patients with prolactinomas. Neuroendocrinology. 2015;101(1):66-81.

217. Ónnestam L, Berinder K, Burman P, Dahlqvist P, Engström BE, Wahlberg J, Nyström HF. National incidence and prevalence of TSH-secreting pituitary adenomas in Sweden. J Clin Endocrinol Metab. 2013:98(2):626-35.

218. Beck-Peccoz P, Brucker-Davis F, Persani L, Smallridge RC, Weintraub BD. Thyrotropin-secreting pituitary tumors. Endocr Rev. 1996;17(6):610-38.

219. Buchfelder M, Fahlbusch R. Thyrotroph adenomas. In: Thapar K, Kovacs K, Scheithauer BW, Lloyd RV, editors. Diagnosis and Management of Pituitary Tumors. Totowa: Humana Press; 2001. p. 333-42.

220. Beck-Peccoz P, Lania A, Beckers A, Chatterjee K, Wemeau JL. 2013 European thyroid association guidelines for the diagnosis and treatment of thyrotropin-secreting pituitary tumors. Eur Thyroid J. 2013;2(2):76-82.

221. Salvatore D, Davies TF, Schlumberger M-J, Hay ID, Larsen PR. Thyroid physiology and diagnostic evaluation of patients with thyroid disorders. Chapter 11. In: Melmed S, Polonsky KS, Larsen PR, Kronenberg HM, editors. Williams Textbook of Endocrinology. 12th ed. Philadelphia: Elsevier Saunders; 2012. p. 327.

222. Miller A, Doll H, David J, Wass J. Impact of musculoskeletal disease on quality of life in long-standing acromegaly. Eur J Endocrinol. 2008;158(5): 587-93.

223. Damjanovic SS, Neskovic AN, Petakov MS, Popovic V, Vujisic B, Petrovic M, Nikolic-Djurovic M, Simic M, Pekic S, Marinkovic J. High output heart failure in patients with newly diagnosed acromegaly. Am J Med. 2002;112(8):610-6,

224. Berg C, Petersenn S, Lahner H, Herrmann BL, Buchfelder M, Droste M, Stalla GK, Strasburger CJ, Roggenbuck U, Lehmann N, Moebus S, Jöckel KH, Möhlenkamp S, Erbel R, Saller B, Mann K, Investigative Group of the Heinz Nixdorf Recall Study and the German Pegvisomant Observational Study Board and Investigators. Cardiovascular risk factors in patients with uncontrolled and long-term acromegaly: comparison with matched data from the general population and the effect of disease control. J Clin Endocrinol Metab. 2010;95(8):3648-56.

225. van der Klaauw AA, Bax JJ, Roelfsema F, Bleeker GB, Holman ER, Corssmit EP, van der Wall EE, Smit JW, Romijn JA, Pereira AM. Uncontrolled acromegaly is associated with progressive mitral valvular regurgitation. Growth Horm IGF Res. 2006;16(2):101-7.

226. Grynberg M, Salenave S, Young J, Chanson P. Female gonadal function before and after treatment of acromegaly. J Clin Endocrinol Metab. 2010; 95(10):4518-25.

227. Anagnostis P, Efstathiadou ZA, Polyzos SA, Adamidou F, Slavakis A, Sapranidis M, Litsas ID, Katergari S, Selalmatzidou D, Kita M. Acromegaly: presentation, morbidity and treatment outcomes at a single centre. Int J Clin Pract. 2011;65(8):896-902.

228. Bogazzi F, Battolla L, Spinelli C, Rossi G, Gavioli S, Di Bello V, Cosci C, Sardella C, Volterrani D, Talini E, Pepe P, Falaschi F, Mariani G, Martino E. Risk factors for development of coronary heart disease in patients with acromegaly: a five-year prospective study. J Clin Endocrinol Metab. 2007;92(11):4271-7.

229. Celik O, Hatipoglu E, Akhan SE, Uludag S, Kadioglu P. Acromegaly is associated with higher frequency of female sexual dysfunction: experience of a single center. Endocr J. 2013;60(6):753-61.

230. Cannavò S, Condurso R, Ragonese M, Ferraù F, Alibrandi A, Aricò I, Romanello G, Squadrito S, Trimarchi F, Silvestri R. Increased prevalence of restless legs syndrome in patients with acromegaly and effects on quality of life assessed by Acro-QoL. Pituitary. 2011;14(4):328-34.

231. Montini M, Gianola D, Pagani MD, Pedroncelli A, Caldara R, Gherardi F, Bonelli M, Lancranjan I, Pagani G. Cholelithiasis and acromegaly: therapeutic strategies. Clin Endocrinol (Oxf). 1994;40(3):401-6.

232. Schmid C, Goede DL, Hauser RS, Brändle M. Increased prevalence of high Body Mass Index in patients presenting with pituitary tumours: severe obesity in patients with macroprolactinoma. Swiss Med Wkly. 2006;136(15-16):254-8.

233. Renehan AG, Bhaskar P, Painter JE, O'Dwyer ST, Haboubi N, Varma J, Ball SG, Shalet SM. The prevalence and characteristics of colorectal neoplasia in acromegaly. J Clin Endocrinol Metab. 2000;85(9):3417-24.

234. Bogazzi F, Cosci C, Sardella C, Costa A, Manetti L, Gasperi M, Rossi G, Bartalena L, Martino E. Identification of acromegalic patients at risk of developing colonic adenomas. J Clin Endocrinol Metab. 2006;91(4):1351-6.

235. Feelders RA, Pulgar SJ, Kempel A, Pereira AM. The burden of Cushing's disease: clinical and health-related quality of life aspects. Eur J Endocrinol. 2012;167(3):311-26.
236. Albiger NM, Occhi G, Sanguin F, lacobone M, Casarrubea G, Ferasin S, Mantero F, Scaroni C. Adrenal nodules in patients with Cushing's disease: prevalence, clinical significance and follow-up. J Endocrinol Invest. 2011; 34(8):e204-9.

237. Invitti C, Manfrini R, Romanini BM, Cavagnini F. High prevalence of nodular thyroid disease in patients with Cushing's disease. Clin Endocrinol (Oxf). 1995;43(3):359-63.

\section{Submit your next manuscript to BioMed Central and we will help you at every step:}

- We accept pre-submission inquiries

- Our selector tool helps you to find the most relevant journal

- We provide round the clock customer support

- Convenient online submission

- Thorough peer review

- Inclusion in PubMed and all major indexing services

- Maximum visibility for your research

Submit your manuscript at www.biomedcentral.com/submit
Biomed Central 